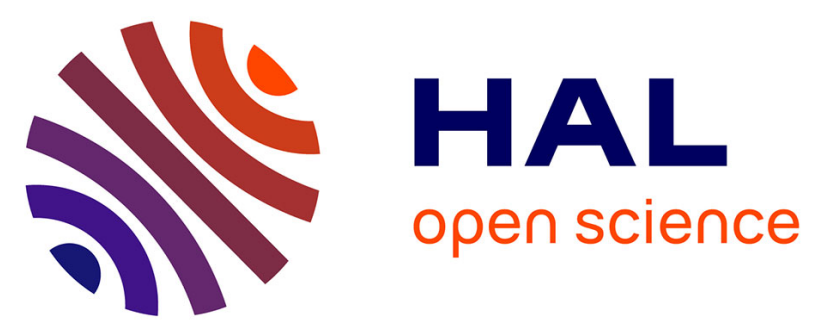

\title{
Micro- to nano-scale characterization of martite from a banded iron formation in India and a lateritic soil in Brazil
}

B. Oberger, C. Wagner, A. Tudryn, Richard Wirth, R. Morgan, J.D. Fabris, Jean-Marc Greneche, C Rosière

\section{To cite this version:}

B. Oberger, C. Wagner, A. Tudryn, Richard Wirth, R. Morgan, et al.. Micro- to nano-scale characterization of martite from a banded iron formation in India and a lateritic soil in Brazil. Physics and Chemistry of Minerals, 2014, 41 (9), pp.651-667. 10.1007/s00269-014-0679-8 . hal-01000772

\section{HAL Id: hal-01000772 \\ https://hal.sorbonne-universite.fr/hal-01000772}

Submitted on 15 Jun 2017

HAL is a multi-disciplinary open access archive for the deposit and dissemination of scientific research documents, whether they are published or not. The documents may come from teaching and research institutions in France or abroad, or from public or private research centers.
L'archive ouverte pluridisciplinaire HAL, est destinée au dépôt et à la diffusion de documents scientifiques de niveau recherche, publiés ou non, émanant des établissements d'enseignement et de recherche français ou étrangers, des laboratoires publics ou privés. 


\title{
2 Micro- to nano-scale characterization of martite from a banded iron formation in India and a lateritic soil in Brazil
}

\author{
4 Beate Orberger - Christiane Wagner • Alina Tudryn • \\ Richard Wirth · Rachael Morgan · José D. Fabris • \\ 6 Jean Marc Greneche $\cdot$ Carlos Rosière
}

\begin{abstract}
The pseudomorphic transformation of magnetite into hematite (martitization) is widespread in geological environments, but the process and mechanism of this transformation is still not fully understood. Micro- and nanoscale techniques-scanning electron microscopy, focused ion bean transmission electron microscopy, and Raman spectroscopy-were used in combination with X-ray diffraction, Curie balance and magnetic hysteresis analyses, as well as Mössbauer spectroscopy on martite samples from a banded iron formation $(2.9 \mathrm{Ga}$, Dharwar Craton, India), and from lateritic soils, which have developed on
\end{abstract}

\section{B. Orberger $(\square)$}

ERAMET RESEARCH, 1 Avenue Albert Einstein,

78190 Trappes, France

e-mail: beate.orberger1@orange.fr

B. Orberger $\cdot$ A. Tudryn $\cdot$ R. Morgan

Université Paris-Sud, Laboratoire GEOPS,

UMR 8148 (CNRS-UPS), Bât 504, 91405 Orsay, France

C. Wagner

UPMC, Univ Paris 06, ISTeP, CNRS, UMR 7193, 4 Place

Jussieu, 75005 Paris, France

R. Wirth

Department 4, GeoForschungsZentrum Potsdam (GFZ),

Telegrafenberg, 14482 Potsdam, Germany

\section{J. D. Fabris}

Universidade Federal dos Vales do Jequitinhonha e Mucuri,

Diamantina, Minas Gerais 39100-00, Brazil

\section{J. M. Greneche}

LUNAM, Institut des Molécules et Matériaux du Mans, IMMM

UMR CNRS 6283, Université du Maine, 72085 Le Mans, France

\section{Rosière}

Instituto de Geociências, Universidade Federal de Minas Gerais,

Belo Horizonte, Minas Gerais 31270-901, Brazil siliciclastic and volcanic rocks previously affected by metamorphic fluids (Minas Gerais, Brazil). Octahedral crystals from both samples are composed of hematite with minor patches of magnetite, but show different structures. The Indian crystals show trellis of subhedral magnetite hosting maghemite in sharp contact with interstitial hematite crystals, which suggests exsolution along parting planes. Grain boundary migrations within the hematite point to dynamic crystallization during deformation. Dislocations and fluid inclusions in hematite reflect its precipitation related to a hydrothermal event. In the Brazilian martite, dislocations are observed and maghemite occurs as Insel structures and nano-twin sets. The latter, typical for the hematite, are a transformation product from maghemite into hematite. For both samples, a deformation-induced hydrothermally driven transformation from magnetite via maghemite to hematite is proposed. The transformation from magnetite into maghemite comprises intermediate non-stoichiometric magnetite steps related to a redox process. This study shows that martite found in supergene environment may result from earlier hypogene processes.

Keywords Magnetite $\cdot$ Hematite Maghemite FIB-TEM $\cdot$ Raman $\cdot$ Mössbauer

In nature, magnetite is transformed into hematite often via pseudomorphic replacement, which was first described by Gruner (1922, 1926, 1929). The chemical and crystallographic transformation of magnetite $\left(\mathrm{FeOFe}_{2} \mathrm{O}_{3}\right.$, cubic crystallographic structure) into hematite $\left(\alpha-\mathrm{Fe}_{2} \mathrm{O}_{3}\right.$, trigonal) perfectly preserves the octahedral crystal habit of the magnetite precursor. This replacement (or martitization)

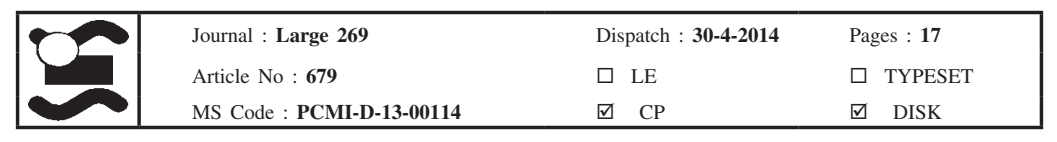


leads to the formation of so-called "martite". In the text, the word "martitization and martite" will thus be used as defined above and as used by, e.g., Swanson-Hysell et al. (2011) and papers therein. The magnetite replacement by hematite can occur during oxidation via $\mathrm{O}^{2-}$ addition or $\mathrm{Fe}^{2+}$ loss (Lepp 1957; Davis et al. 1968). Alternatively, a dissolution-precipitation process (chemically or biochemically mediated) can be controlled by $\mathrm{pH}$ changes (Brown et al. 1997; Ohmoto 2003; Otake et al. 2007) or by deformation (Lagoeiro 1998). All these processes have been proposed for banded iron formations (BIFs), where the magnetite-hematite transformation is common (Banerji 1984; Morris 1985; Ohmoto 2003; Mücke and Cabral 2005; Beukes et al. 2008). The transformation can occur directly from magnetite to hematite, as mainly observed in low-temperature sedimentary environments, or via maghemite formation $\left(\gamma-\mathrm{Fe}_{2} \mathrm{O}_{3}\right.$, cubic with a tetragonal supercell) as an intermediate step (Bachmann 1954; Lepp 1957; Colombo et al.1965; Davis et al. 1968; Morris 1980, 1985; Banerji 1984). The metastability of maghemite compared to hematite has been much debated (see the review of Lindsley 1976 and references therein). Maghemite has an irondeficient spinel structure with vacancies distributed among the octahedral and tetrahedral sites (e.g., "kenotetrahedral magnetite" from Kullerud et al. 1969; Weber and Hafner 1971). According to Linsdley (op. cit.), these spinels are considered either as "omission solid solution between magnetite and $\gamma$-(or $\alpha$-) $\mathrm{Fe}_{2} \mathrm{O}_{3}$ " or simply as "cation-deficient magnetites". We use hereafter the term of "non-stoichiometric magnetite" for these intermediate products.

This is the first study on martite using micro- and nanoscale methods, scanning electron microscopy (SEM), focused ion bean transmission electron microscopy (FIBTEM) and micro-Raman spectroscopy, which were crossed with X-ray diffraction (XRD), Mössbauer spectroscopy, Curie balance and magnetic hysteresis in order to understand the processes and mechanisms of the magnetite-hematite transformation. We studied two samples from different geological environments. The first belongs to chemically precipitated BIFs, which were affected by lower greenschist facies metamorphism (Bababudan Group; 2.9 Ga, Mid-Archean Western Dharwar Craton, Southern India; Orberger et al. 2012). The second sample comes from a lateritic soil, which developed on siliciclastic and volcanic rocks previously affected by metamorphic fluids (MidProterozoic Espinhaço Supergroup, Minas Gerais, Brazil; Cabral et al. 2011, 2012 and references therein).

\section{Sample description}

The Brazilian sample consists of millimetric octahedral crystals from a lateritic soil developed on phyllites of the Espinhaço Supergroup (Serra do Espinhaço, Minas Gerais, Brazil, south of the Guinda, southeast of Diamantina $\left(18^{\circ} 17^{\prime} 31.12^{\prime \prime} \mathrm{S}, 43^{\circ} 38^{\prime} 09.75^{\prime \prime} \mathrm{W}\right.$; Fig. 1a). These rocks
Fig. 1 Brazilian sample from the Espinhaço Range, Minas Gerais. a Octahedral crystals. Reflected light microphotographs, polished thin section. b Hematite of platy structure. c Hematite (white) replacing magnetite (gray). mag magnetite, $\mathrm{hm}$ hematite
99
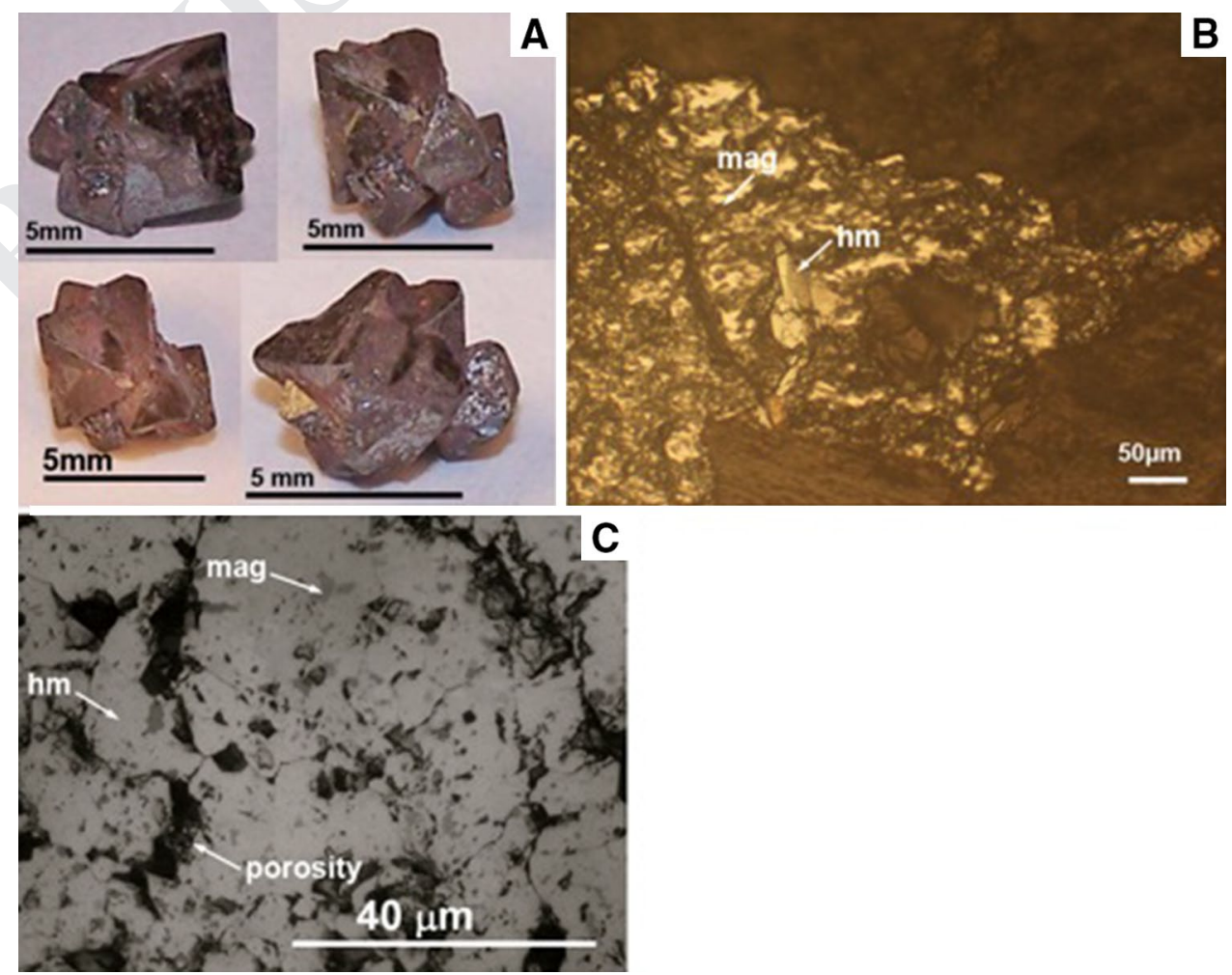

\begin{tabular}{|c|c|c|c|}
\hline & Journal : Large 269 & Dispatch : 30-4-2014 & Pages : 17 \\
\hline & Article No : 679 & $\square$ LE & $\square$ TYPESET \\
\hline & MS Code : PCMI-D-13-00114 & $\nabla \quad \mathrm{CP}$ & DISK \\
\hline
\end{tabular}


Fig. 2 a Scanned polished thin section of the Indian sample (B14a) from the Dharwar Craton showing alternating iron oxide (dark) and quartz bands (bright). b and c SEMBSE microphotographs of a subhedral iron oxide crystal showing a trellis, intergrown with quartz. d Reflected light microphotograph of iron oxide crystals. Hematite (white) is the major phase with relicts patches of magnetite (gray) and rare goethite (darker gray). Symbols as in Fig. 1

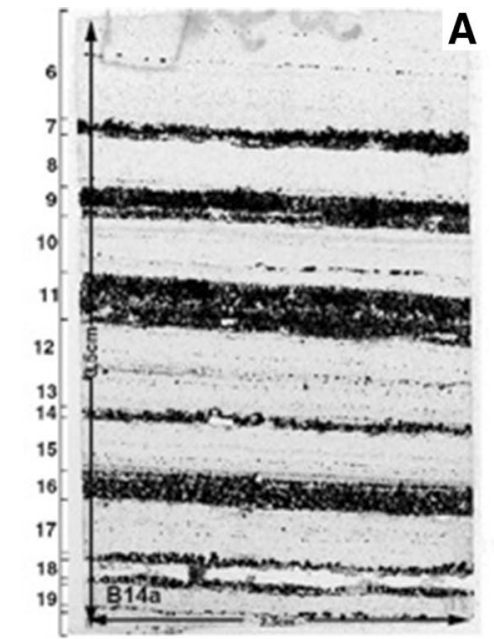

A

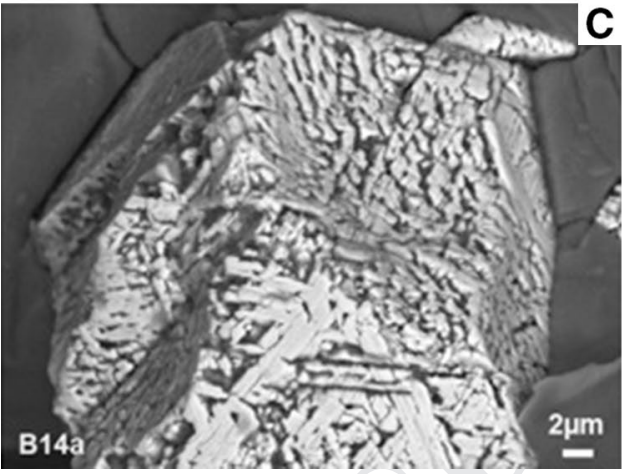

contain magnetite, hematite and tourmaline and host hydrothermal quartz veins with irregular aggregates of magnetite and tourmaline randomly distributed over the metamorphic fabric (Cabral et al. 2011, 2012).

The micro-texture of the Brazilian sample shows subto euhedral hematite octahedral grains $(20-40 \mu \mathrm{m})$ showing intergranular porosity (Fig. 1b, c). On the outer crystal faces, carbonaceous matter was observed. Some platy hematite crystals $(\sim 20 \mu \mathrm{m})$ occur in linear clusters along crystal planes (Fig. 1b). Magnetite relicts are still present (Fig. 1c).

The Indian sample (B14a) comes from the 500-m-thick Archean BIF of the Bababudan Group in the Western Dharwar Craton, Southern India (N 13⒈ $9^{\prime} 539^{\prime \prime}$, E $76^{\circ} 42^{\prime} 300^{\prime \prime}$ ), herein referred to as the Indian sample. The BIF chemically precipitated from a mixture of hydrothermal and seawater fluids (Kumar and Das Sharma 1998; Srinivasan and Ojakangas 1986; Orberger et al. 2012) and experienced greenschist facies metamorphism (Taylor et al. 1984; Jayananda et al. 2006; Sarma et al. 2011). The Indian sample is characterized by alternating millimetric layers of gray $\mathrm{Fe}$-oxide and white quartz (Fig. 2a). The Fe-oxide layers consist of cubic or octahedral crystals $(\sim 20 \mu \mathrm{m})$ of hematite, showing a trellis pattern (Fig. 2b, c) with relicts of magnetite and rare goethite patches (Fig. 2d). Modern weathering led to the formation of goethite (Orberger et al. 2012).

\section{Methods}

Polished thin sections of both Brazilian and Indian samples were studied using reflected and transmitted light optical microscopy, SEM and TEM and micro-Raman spectroscopy. XRD, Curie balance, magnetic hysteresis and Mössbauer spectrometry were performed on powders of a few macroscopic octahedra from the Brazilian sample and three separate fractions (total sample material, magnetic fraction and rest) of a massive Fe-oxide band from the Indian BIF.

\section{SEM and TEM}

Backscattered electron (BSE) imaging was performed using SEM Philips XL 30 connected to an EDX-PGT Ge detector for semi-quantitative chemical analyses (20$30 \mathrm{kV}$ ) at the Universite de Paris Sud XI and SEM Zeiss SUPRA 55VP at the Université Paris 06 (UPMC), Paris. Focused ion beam (FIB) technique was used to cut slices with dimensions of $10 \times 10 \times 0.1 \mu^{3}$ for TEM. Details of the FIB milling process were given in Wirth $(2004,2009)$. TEM was performed using a FEI F20 X-Twin microscope with a Schottky field emitter as an electron source at GFZPotsdam, Germany. The TEM mode was used to assess the bright and dark field imaging and selected area electron

\begin{tabular}{|llll|} 
Journal : Large 269 & Dispatch : 30-4-2014 & Pages : 17 \\
Article No : 679 & $\square$ LE & $\square$ TYPESET \\
MS Code : PCMI-D-13-00114 & $\square \quad C P$ & $\square$ & DISK \\
\hline
\end{tabular}


diffraction (SAED). A Fishione high-angle annular dark field (HAADF) detector enables Z-contrast imaging. The chemical composition of selected spots was determined with an EDAX X-ray analyzer with ultra-thin window and a Li-doped silicon detector.

\section{Micro-Raman spectroscopy}

Raman spectroscopy was performed at the Laboratoire de Sciences de la Terre, ENS-Lyon, Lyon, France, using a Horiba Jobin-Yvon Labram HR800 spectrometer, equipped with a microscope for the backscattered Raman signal collection. Oxide phases were characterized through unpolarized Raman spectra within 30-60 s. The excitation source was an argon ion laser beam at $\lambda=514.5 \mathrm{~nm}$. The lateral resolution of the focused laser probe was measured at $1 \mathrm{~mm}$ using $100 \times$ objective magnitude. The laser power measured at the sample was $500 \mu \mathrm{W}$. Calibration was performed during measurements in a silicon semiconductor mode at $520.7 \mathrm{~cm}^{-1}$. The spectral signals were recorded in the range between 150 and $1,800 \mathrm{~cm}^{-1}$. The spectral resolution was $\sim 2-4 \mathrm{~cm}^{-1}$ (with diffraction grating of $600 \mathrm{gr} \mathrm{mm}^{-1}$ for the Indian sample and 1,800 $\mathrm{gr} \mathrm{mm}^{-1}$ for the Brazilian sample). The Raman spectra were processed by the PeakFit 4.0 (Jandel Scientific) software using Loess smoothing procedure and second-order polynomial function for baseline fitting. The peak wave numbers were determined assuming a Lorentzian line shape.

Laser-induced thermal effects are known to affect iron oxides and hydroxides, but sample degradation can be avoided using a laser power on the sample below $1 \mathrm{~mW}$ (Shebanova and Lazor 2003a; Gehring et al. 2009; El Mendili et al. 2010). Thus, a low 500- $\mu \mathrm{W}$ power was used here, and moreover, we check for any possible degradation by acquiring several spectra at the same location for a total time of $8 \mathrm{~min}$ on a goethite patch in the Indian sample as shown in "Appendix". Apart from the expected lowering of the background fluorescence with increasing acquisition time, no significant changes in position, shape, or width of the goethite characteristic peaks are noticeable. This rules out any laserinduced goethite dehydration and transformation to hematite.

\section{XRD analyses}

XRD analyses were performed at the UMR IDES, Université Paris Sud XI, using a Philips apparatus with $\mathrm{Cu}$ $\alpha$ cathode during a 4-h run between $6^{\circ}$ and $80^{\circ}(2 \theta)$. For the Brazilian sample, two more 3-h runs were performed in the ranges $34^{\circ}-40^{\circ}$ and $51^{\circ}-67^{\circ}$ in order to distinguish between overlapping peaks of magnetite, maghemite and hematite (Fig. 3c, d). Calibration of the XRD spectra was performed with quartz, which is finely intergrown with the Fe-oxides in the Indian sample. The precision is $0.004 \AA$.
Magnetic parameter analyses

The thermomagnetic behavior of the samples was determined on a horizontal force translation balance at UMR IDES, Université Paris Sud XI. Analyses were performed in air atmosphere, in a magnetic field of $0.375 \mathrm{~T}$ and linear temperature increase of $10{ }^{\circ} \mathrm{C} \mathrm{min}{ }^{-1}$. Magnetic hysteresis measurements were taken at room temperature with an alternating gradient magnetometer (AGM 2900-Micromag) at the LSCE-CNRS/CEA laboratory at Gif-sur-Yvette, France. A peak-applied field of $1 \mathrm{~T}$ was used for hysteresis measurements. The values of saturation magnetization $\left(M_{\mathrm{s}}\right)$, saturation remnant magnetization $\left(M_{\mathrm{rs}}\right)$ and coercive force $\left(B_{\mathrm{c}}\right)$ were estimated from the hysteresis loop; $M_{\mathrm{S}}$ and $M_{\mathrm{rs}}$ were mass normalized. Coercivity of remanence $\left(B_{\mathrm{cr}}\right)$ was obtained by step-wise application of back fields to remove the saturation remanence. The magnetic hysteresis parameters are given in Table 1.

${ }^{57} \mathrm{Fe}-$ Mössbauer spectrometry

${ }^{57} \mathrm{Fe}$-Mössbauer spectrometry was carried out at the Institut des Molécules et Matériaux du Mans, Université du Maine, Le Mans, France. Spectra were recorded in transmission geometry at $300 \mathrm{~K}$ using a ${ }^{57} \mathrm{Co} / \mathrm{Rh} \gamma$-ray source mounted on a conventional constant acceleration electromagnetic drive. The hyperfine structure was analyzed by means of a least squares fitting method involving magnetic components with Lorentzian lines. The fitting procedure allows estimating the hyperfine parameters of each $\mathrm{Fe}$ species on their respective atomic proportions. The isomer shift values $(\delta)$ are referred to $\alpha-\mathrm{Fe}$ at $300 \mathrm{~K}$ (Table 2).

\section{Results}

X-ray diffraction

A careful study of the diffraction patterns is needed in order to discriminate between the different $\mathrm{Fe}$-oxides due to peak overlapping of, for example, the major peaks $(I=100)$ of magnetite (2.532 $\AA$, JCPDS 19-629; Joint Committee on Powder Diffraction Standard 1974), maghemite (2.52 A, JCPDS 4-755) and hematite $(I=50 ; 2.52 \AA)$, or the peak at $1.48 \AA(I=40-50)$ present in these three Fe-oxides.

\section{Brazilian sample}

A well-crystallized hematite with strong and sharp reflection peaks is the major compound (Fig. 3a). The presence of maghemite is revealed by the peak at $2.782 \AA[I=19$ (221); Fig. 3b], while the shoulder at $2.532 \AA$ on the major hematite peak [2.518 $\AA$ (311); Fig. 3d] could be attributed

\begin{tabular}{|llll|} 
Journal : Large 269 & Dispatch : 30-4-2014 & Pages : 17 \\
Article No : 679 & $\square$ LE & $\square$ TYPESET \\
MS Code : PCMI-D-13-00114 & $\square \quad C P$ & $\square$ & DISK \\
\hline
\end{tabular}


Fig. 3 XRD patterns of the Brazilian sample. a Total spectrum, 4-h run, range $6^{\circ}-80^{\circ}$

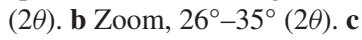
and $\mathbf{d}$ 3-h spectrum for the key areas $51^{\circ}-67^{\circ}(2 \theta)$ and $34^{\circ}-40^{\circ}$ $(2 \theta)$, respectively. He hematite, $M g$ magnetite, $M h$ maghemite, $Q z$ quartz, $G$ goethite
Brazil
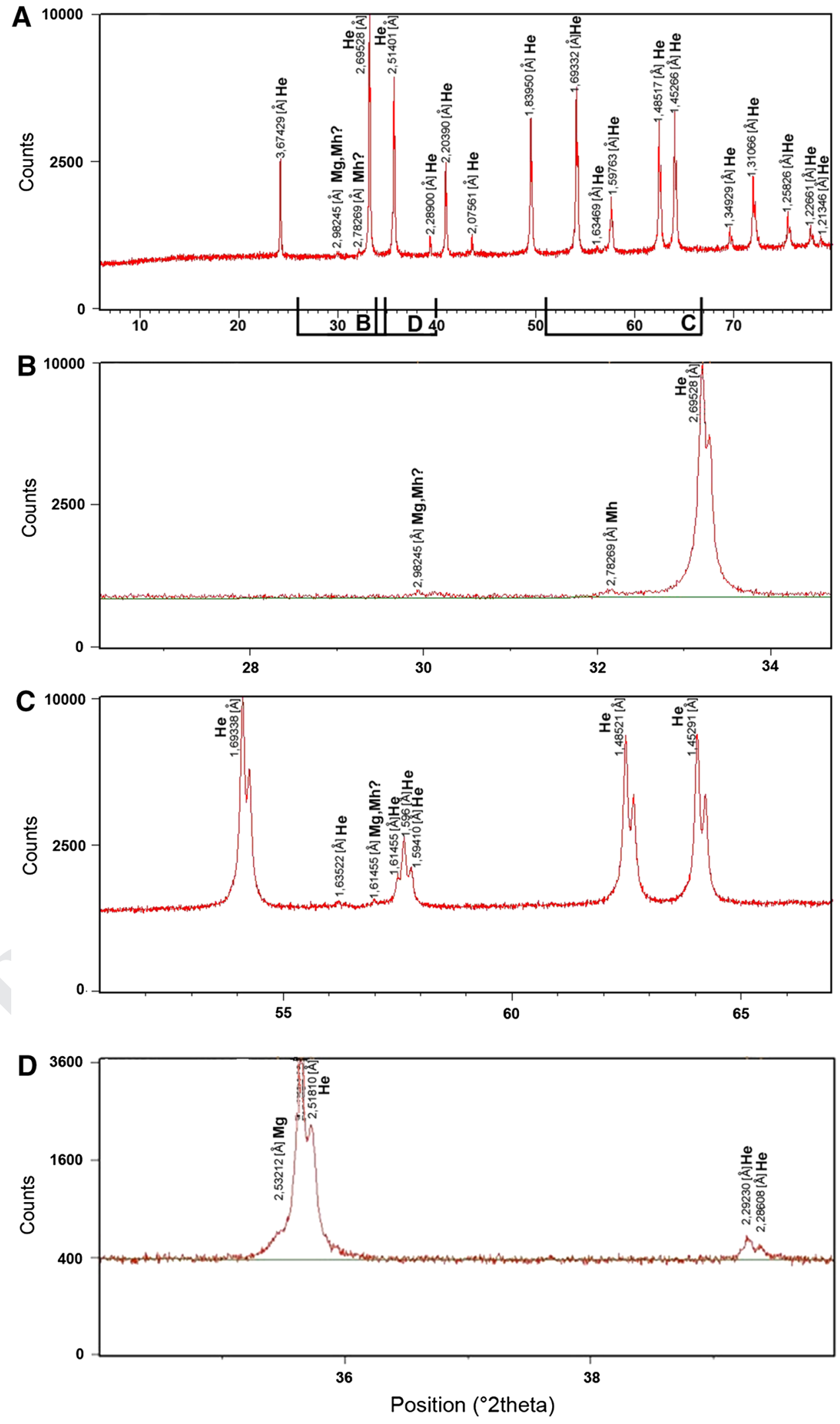
Table 1 Magnetic hysteresis parameters

\begin{tabular}{|c|c|c|c|c|c|c|}
\hline Samples & $B_{\mathrm{c}}(\mathrm{mT})$ & $B_{\mathrm{cr}}(\mathrm{mT})$ & $M_{\mathrm{rs}} / \mathrm{masse}\left(\mu \mathrm{Am}^{2} / \mathrm{mg}\right)$ & $M_{\mathrm{s}} / \mathrm{masse}\left(\mu \mathrm{Am}^{2} / \mathrm{mg}\right)$ & $M_{\mathrm{rs}} / M_{\mathrm{s}}$ & $B_{\mathrm{cr}} / B_{\mathrm{c}}$ \\
\hline Brazil & 19.7 & 221.5 & 0.27 & 0.86 & 0.31 & 11.24 \\
\hline India total & 18.8 & 62.4 & 0.28 & 1.62 & 0.17 & 3.32 \\
\hline India extract & 12.9 & 46 & 0.58 & 4.67 & 0.12 & 3.57 \\
\hline India rest & 21.5 & 78.3 & 0.22 & 1.12 & 0.20 & 3.64 \\
\hline
\end{tabular}

$B_{\mathrm{c}}$ coercive force, $B_{\mathrm{cr}}$ coercivity of remanence, $M_{\mathrm{rs}}$ remanent magnetization, $M_{\mathrm{s}}$ saturation magnetization

Table 2 Mössbauer spectral parameters at $300 \mathrm{~K}$

\begin{tabular}{llllll}
\hline Values of Mössbauer parameters at $300 \mathrm{~K}$ \\
Sample & $\delta(\mathrm{mm} / \mathrm{s})$ & $2 \varepsilon(\mathrm{mm} / \mathrm{s})$ & $B_{\mathrm{hf}}(\mathrm{T})$ & Proportions & Oxide \\
label & \pm 0.01 & \pm 0.01 & \pm 0.5 & $\pm 2(\%)$ & \\
\hline India total & 0.38 & -0.17 & 51.5 & 86 & $\mathrm{Ht}$ \\
& 0.35 & -0.27 & 37.8 & 14 & $\mathrm{Goeth}$ \\
India MF & 0.63 & $0^{\mathrm{a}}$ & 46.0 & 2 & $\mathrm{Mt}, \mathrm{Fe}^{3+}$ \\
& 0.32 & $0^{\mathrm{a}}$ & $49.0^{\mathrm{a}}$ & 1 & $\mathrm{Mt}, \mathrm{Fe}^{2.5+}$ \\
& 0.38 & -0.17 & 51.5 & 83 & $\mathrm{Ht}$ \\
& 0.37 & -0.26 & 38.0 & 14 & $\mathrm{Goeth}$ \\
India REST & 0.38 & -0.17 & 51.9 & 82 & $\mathrm{Ht}$ \\
& 0.36 & -0.26 & 37.8 & 18 & $\mathrm{Goeth}$ \\
Brazil & 0.38 & -0.18 & 51.7 & 100 & $\mathrm{Ht}$ \\
\hline
\end{tabular}

Three separate fractions were analyzed for the Indian sample: total, magnetic fraction (MF), and rest after magnetic extraction (REST). The two components of magnetite were assumed in the expected ratio in the fitting procedure, while their respective hyperfine field $\left(B_{\mathrm{hf}}\right)$, quadrupolar $(2 \varepsilon)$, and isomer $(\delta)$ shift values were fixed to expected values, because of the lack of resolution. The magnetite components were introduced through fitting the Mössbauer spectra of the Total and REST fractions, but the final content was very low $(<5 \%)$

$\mathrm{Ht}$ : hematite; $\mathrm{Mt}, \mathrm{Fe}^{3+}$ and $\mathrm{Mt}, \mathrm{Fe}^{2.5+}$ refer to the magnetite sextets; Goeth: goethite

${ }^{\text {a }}$ Fixed parameter during fitting

to magnetite. Magnetite and/or maghemite may be indexed from the peak at $2.982 \AA$ (Fig. 3b), which could correspond to the peaks 2.96 and $2.95 \AA[I=30$ (220)] of magnetite and maghemite, respectively, and from the peak at $1.614 \AA$ (Fig. 3c), corresponding to the peak at $1.616 \AA(I=30 / 33$, 511 or 333 ) of the two oxides.

\section{Indian sample}

The XRD spectrum of the total sample-prior to magnetic separation-shows the presence of quartz (JCPDS 5-615), hematite and goethite (JCPDS 17-536) (Fig. 4a). Hematite is the major compound showing strong and sharp reflections, while the goethite peaks are asymmetric and show a large half-peak width, which is indicative for poor crystallinity (Fig. 4b, c). A very small peak appears at $2.787 \AA$, characteristic for maghemite, and at
$2.969 \AA$ for possibly magnetite or maghemite (Fig. 4b). In the magnetic fraction, the same minerals as in the total sample are observed, but oxide peaks show higher intensities (Fig. 5a, c). The weak peak at $1.613 \AA$ (Fig. 5c) may indicate magnetite or maghemite. The peak at $\sim 2.5 \AA$ (Fig. 5b) is split, suggesting the presence of magnetite (311) and hematite (110) or maghemite (311). The rest of the material-after magnetic separation-shows, as expected, higher intensities of quartz, no peak splitting at $2.5 \AA$, but still a weak peak at $2.973 \AA$ (Fig. 6b) attributed to magnetite or maghemite.

Magnetic parameters

Both samples show a mixture of magnetite and hematite, with Curie temperatures of 580 and $680{ }^{\circ} \mathrm{C}$, respectively (Fig. 7a, b, d). In this range of temperatures, the higher intensity of the relative magnetization $\left(M / M_{\mathrm{S}}\right)$ in the Brazilian sample compared to the Indian total fraction (Fig. 7a, b) suggests a higher content of hematite relative to magnetite in the former. In the Indian magnetic fraction (Fig. 7c), low $M / M_{\mathrm{s}}$ reflects the dominance of magnetite, a soft ferrimagnetic magnetite easily magnetized and extracted from the total sample compared to hard weak magnetic hematite (canted antiferromagnetic), while hematite controls higher $M / M_{\mathrm{s}}$ in the Indian rest after magnetic extraction (Fig. 7d). The decrease in relative magnetization just below $400{ }^{\circ} \mathrm{C}$ (Fig. 7a) in the Brazilian sample, as well as the very slight decrease in the Indian rest fraction (Fig. 7d), indicates that another magnetic phase is present such as maghemite, which commonly transforms into hematite at that temperature (e.g., Tarling 1983; Thompson and Oldfield 1986; De Boer and Dekkers 2001).

Magnetic hysteresis loops are presented in Fig. 7e, h and hysteresis characterizing parameters in Table 1 . The magnetic hysteresis loops of the Brazilian sample and the Indian total and rest fractions (Fig. 7e, f, h) are constricted in the middle section, and wider above and below the middle section. Such "wasp-waisted" hysteresis loops indicate different magnetic components with contrasting coercive fields and may correspond to (1) a mixture of different grain sizes of a single magnetic mineral, (2) a mixture of different magnetic materials with largely
270

271 272 273 274 275 276 277 278 279 280 281 282 283 284 285 286 287 288 289 290 291 292 293 294 295 296 297 298 299

\begin{tabular}{l|lll|} 
Journal : Large 269 & Dispatch : 30-4-2014 & Pages : 17 \\
Article No : 679 & $\square$ LE & $\square$ TYPESET \\
MS Code : PCMI-D-13-00114 & $\square \quad C P$ & $\square$ DISK \\
\hline
\end{tabular}


Fig. 4 XRD patterns of the total Indian. a Total spectrum, 4-h run, range $6^{\circ}-80^{\circ}(2 \theta)$.

b Zoom, range $29^{\circ}-42^{\circ}(2 \theta)$

c Zoom, range $51^{\circ}-67^{\circ}(2 \theta)$.

Same symbols as in Fig. 3
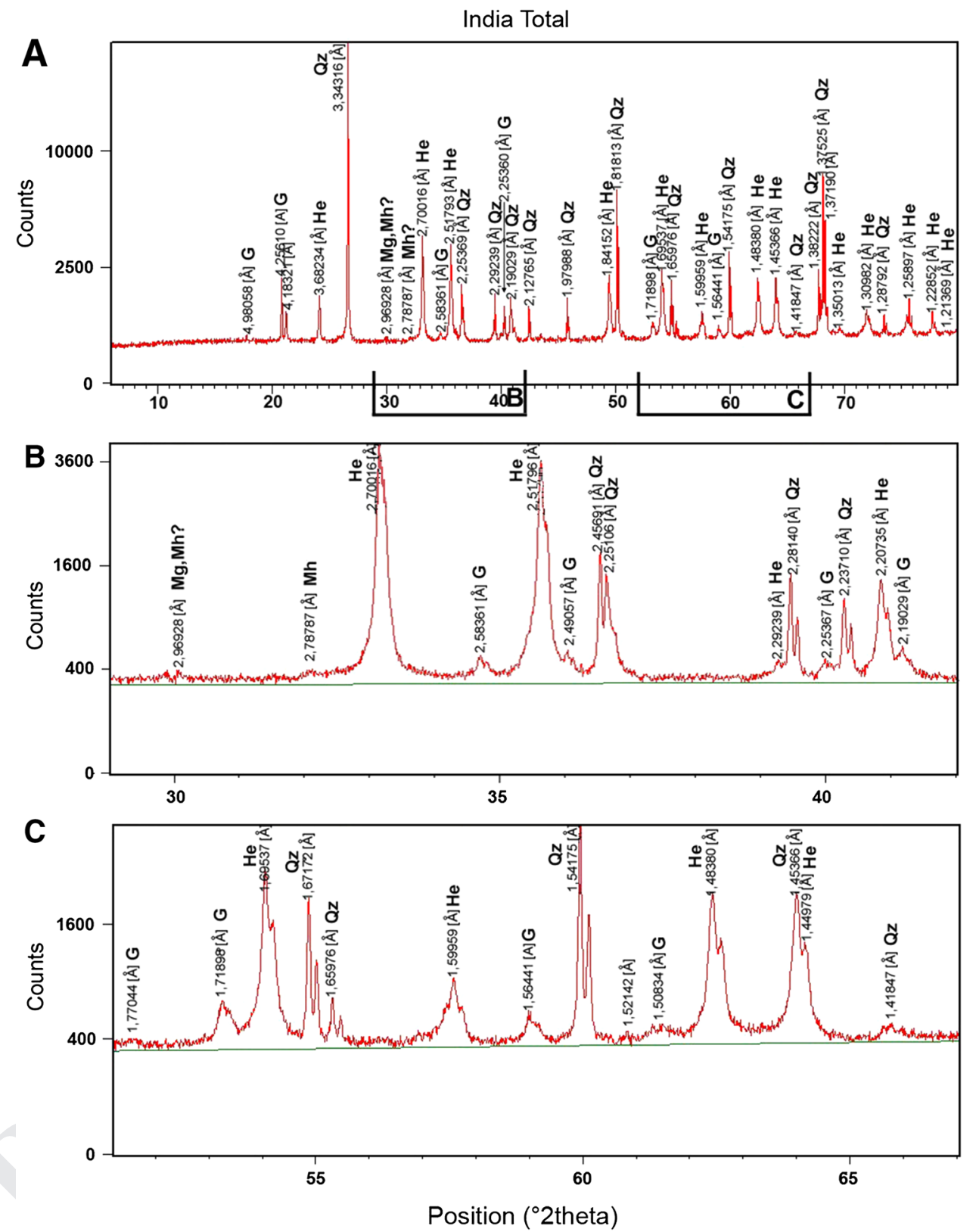

different coercivities, or (3) a combination of both possibilities (e.g., Wasilewski 1973; Day et al. 1977; Roberts et al. 1995; Tauxe et al. 1996). When different magnetic components are present, the soft (low coercivity) component controls the coercive force $\left(B_{\mathrm{c}}\right)$, while the hard (high coercivity) component controls the coercivity of remanence $\left(B_{\mathrm{cr}}\right)$. The degree of the constriction in the middle section of the magnetic loop depends on the relative contribution of each component. Furthermore, in the presence of high magnetic moment minerals, such as ferrimagnetic magnetite or maghemite, canted anti-ferromagnetic hematite with weak magnetic moments must be abundant to cause waspwaisted magnetic loops. The wasp-waisted hysteresis loops for the studied samples (Fig. 7e, f, h) result from a mixture of different components. In the Brazilian sample, high $B_{\text {cr }} \quad 314$ (Table 1) and the open nature of the loop at magnetic field 315 values above $0.3 \mathrm{~T}$ (corresponding to the maximum coer- 316 civity of most ferrimagnetic minerals such as magnetite) 317 indicate a relatively higher amount of the hard component 318 hematite ( \pm goethite) compared to magnetite ( \pm maghe- 319 mite) than in the Indian sample (Fig. 7e, f, h). In the Indian 320 sample, low values of $B_{\mathrm{c}}$ (Table 1) indicate the presence of 321 a soft material such as magnetite or maghemite. 322

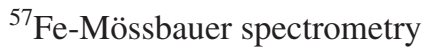
323

The 300-K Mössbauer data of the Indian sample (total, magnetic fraction and rest after magnetic extraction)

\begin{tabular}{|l|ll|}
\hline Journal : Large 269 & Dispatch : 30-4-2014 & Pages : 17 \\
Article No : 679 & $\square$ LE & $\square$ TYPESET \\
MS Code : PCMI-D-13-00114 & $\square \quad C P$ & $\square$ DISK \\
\hline
\end{tabular}


Fig. 5 XRD patterns of the magnetic fraction (MF) of the Indian sample. a Total spectrum, 4-h run, range $6^{\circ}-80^{\circ}$ $(2 \theta)$. b Zoom, range $29^{\circ}-42^{\circ}$

$(2 \theta)$. c Zoom, range $51^{\circ}-67^{\circ}$

(20). Same symbols as in Fig. 3
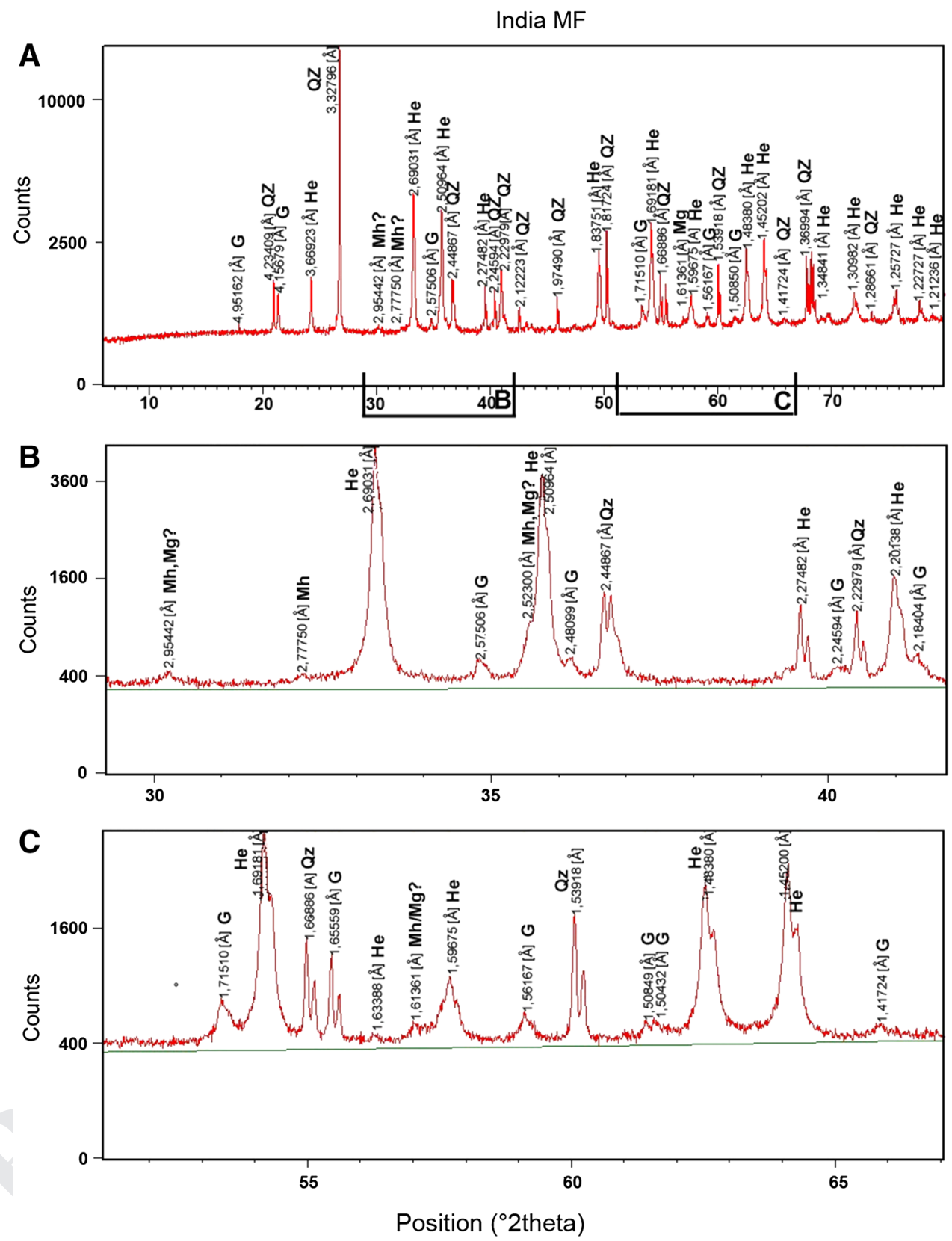

and the Brazilian sample are shown in Table 2, and patterns are shown in Fig. 8. The spectrum for the Brazilian sample consists of a single sextet evidencing the sole occurrence of hematite. Differently, in all spectra for the Indian sample, the hyperfine structure exhibits spectral features that correspond to the two coordination symmetries of iron in magnetite: $\mathrm{Fe}^{3+}$ on tetrahedral and $\mathrm{Fe}^{3+/ 2+}$ on octahedral sites of the spinel structure. Furthermore, in the spectrum for the magnetic fraction of the Indian sample, the inset of Fig. 8 magnifies thethough small-resonance line assignable to iron on octahedral sites of magnetite. Both the total Indian sample and the rest fraction after magnetic extraction indicate the presence of hematite (86 and $82 \%$, respectively) 339 and goethite (14 and $18 \%$, respectively), while only 340 $3 \%$ of magnetic fraction is composed of magnetite and 341 still $83 \%$ represents the hematite. No maghemite was 342 detected in both samples.

Micro-Raman spectroscopy

Brazilian sample

Ten to twenty spectra were collected on selected zones of both samples. Representative Raman spectra are shown in Figs. 9 (Brazil) and 10 (India).
346 347 348

\begin{tabular}{|l|ll|}
\hline Journal : Large 269 & Dispatch : 30-4-2014 & Pages : 17 \\
Article No : 679 & $\square$ LE & $\square$ TYPESET \\
MS Code : PCMI-D-13-00114 & $\square \quad C P$ & $\square$ DISK \\
\hline
\end{tabular}


Fig. 6 XRD patterns of the Indian sample, rest material after magnetic separation. a Total spectrum, 4-h run, range $6^{\circ}-80^{\circ}(2 \theta)$. b Zoom, range $29^{\circ}-42^{\circ}(2 \theta)$. c Zoom, range $51^{\circ}-67^{\circ}(2 \theta)$. Same symbols as in Fig. 3
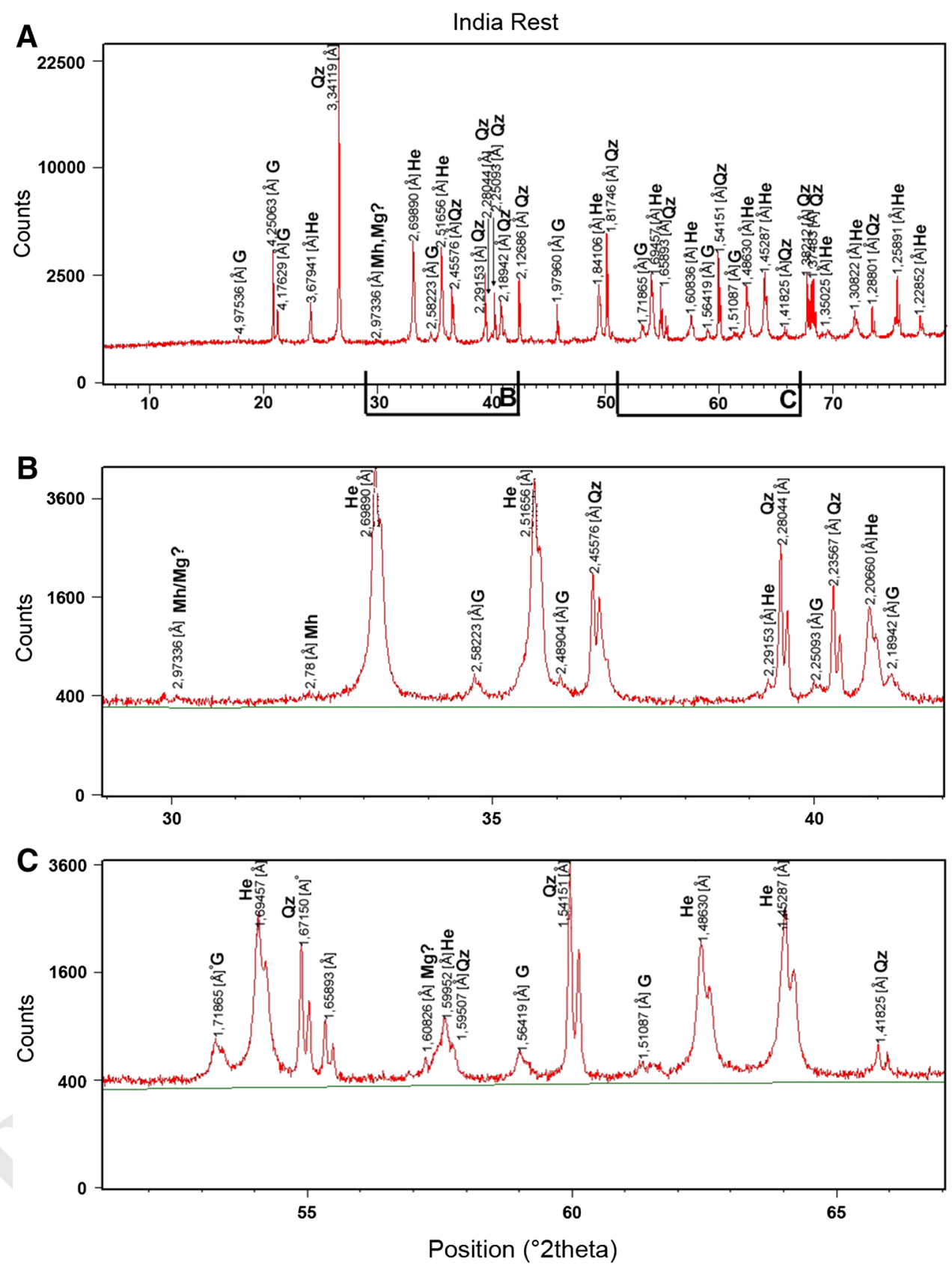

In the Brazilian sample, spectra were recorded from two different grains based on differences in reflected light: (1) rare small $(5-20 \mu \mathrm{m})$ dark grayish patches in (2) overall bright white grains. In the bright areas, the spectra recorded from grain 1 (Fig. 9a) show bands at 222-229, 293-304, 413-419, 505-512, 614-633, 664-679, and $1,336-1,342 \mathrm{~cm}^{-1}$, while in grain 2 (spectrum not shown), an additional band at $248-250 \mathrm{~cm}^{-1}$ appears. The band at $\sim 300 \mathrm{~cm}^{-1}$ may be split into two bands (e.g., 291 and $299 \mathrm{~cm}^{-1}$ ). This combination of bands is typical of hematite (e.g., de Faria et al. 1997; Hanesh 2009). Hematite belongs to the $\mathrm{D}_{3 \mathrm{~d}}^{6}$ spatial group, and seven Raman active modes are expected: two $A_{1 \mathrm{~g}}$ modes at 225 and $498 \mathrm{~cm}^{-1} \quad 361$ and five $\mathrm{E}_{\mathrm{g}}$ modes at 247, 293, 299, 412, and $613 \mathrm{~cm}^{-1}, \quad 362$ and a band at $1,320 \mathrm{~cm}^{-1}$ usually attributed to a two-mag- 363 non scattering (de Faria et al. 1997). Some bands may not 364 be resolved or may only appear on the flank of stronger 365 peaks (e.g., bands at 245 and $299 \mathrm{~cm}^{-1}$ ) as observed here 366 (op. cit.). In our samples, the peak positions are slightly 367 shifted toward greater wave numbers compared to the 368 aforementioned data. This may be due to different laser 369 wavelengths and powers, the crystallinity or the orienta- 370 tion of the sample, and is meaningless. However, the addi- 371 tional band at $668-675 \mathrm{~cm}^{-1}$, the position of the $\mathrm{E}_{\mathrm{g} 5}$ mode 372

\begin{tabular}{|l|lll|}
\hline Journal : Large 269 & Dispatch : 30-4-2014 & Pages : 17 \\
Article No : 679 & $\square$ LE & $\square$ TYPESET \\
MS Code : PCMI-D-13-00114 & $\square \quad$ CP & $\square \quad$ DISK \\
\hline
\end{tabular}


A

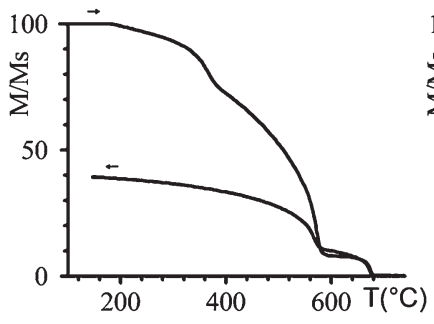

B

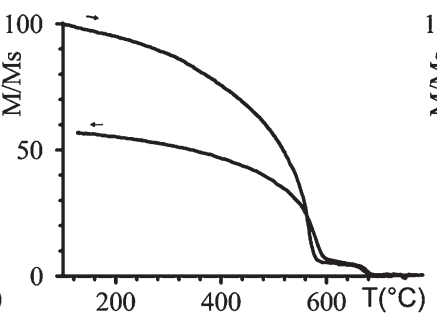

C

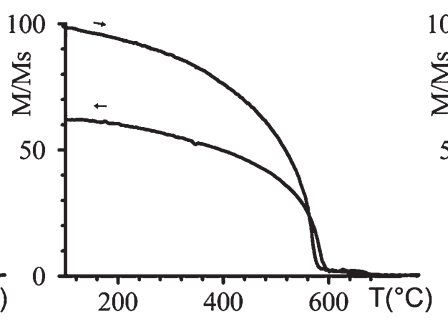

D

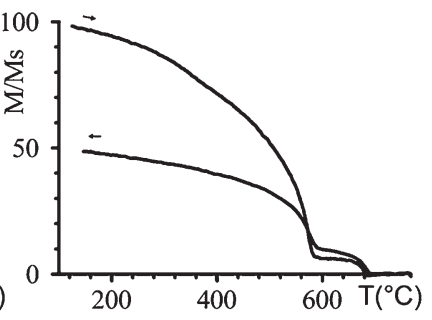

E

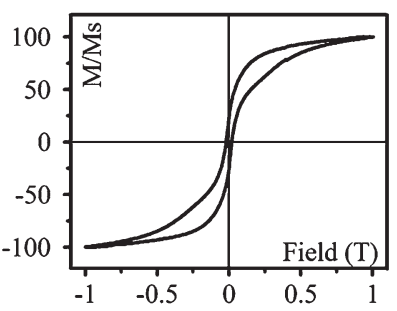

$\mathbf{F}$

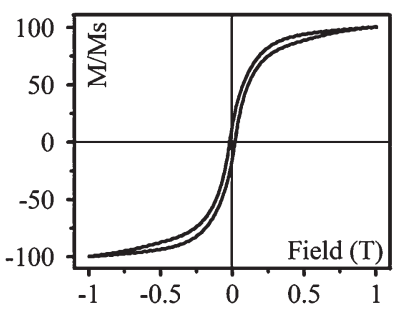

G

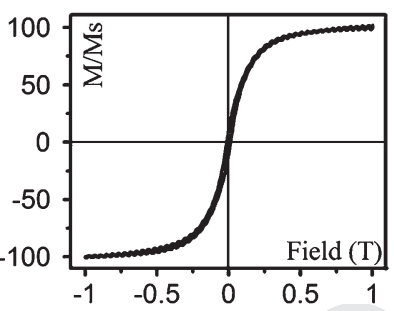

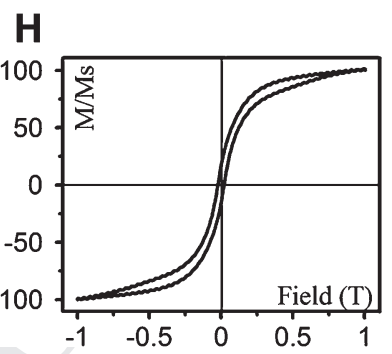

Fig. 7 Thermomagnetic behavior of samples: a Brazilian, b Indian total, c Indian magnetic extraction, d Indian rest, after magnetic extraction. Magnetic hysteresis of the samples: e Brazilian, $\mathbf{f}$ Indian

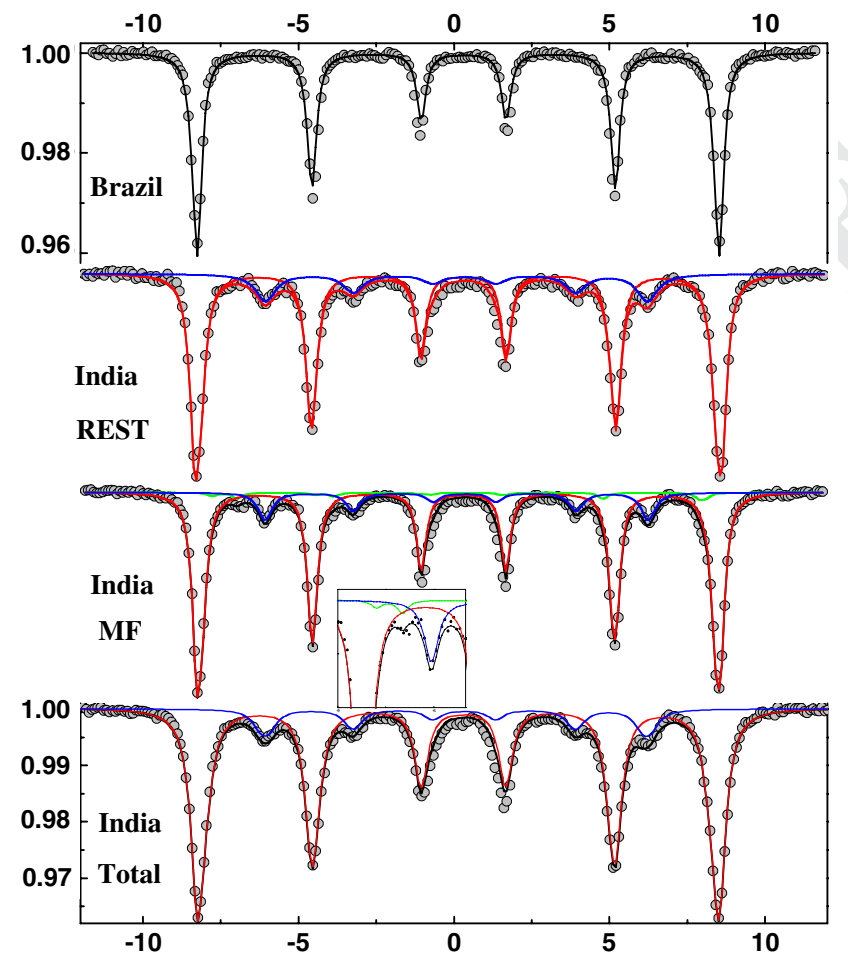

Fig. 8 300-K Mössbauer spectra recorded for the Indian (TOT total sample material, $M F$ magnetic fraction, REST rest after magnetic extraction) and the Brazilian samples at $617-631 \mathrm{~cm}^{-1}$ instead of $613 \mathrm{~cm}^{-1}$, and the position of the magnon band at $1,330-1,340 \mathrm{~cm}^{-1}$ (i.e., a shift up to $20 \mathrm{~cm}^{-1}$ ) are significant. The band at $668-675 \mathrm{~cm}^{-1}$ is in the range reported for the strong $\mathrm{E}_{\mathrm{g}}$ mode of magnetite total, g Indian magnetic extraction, h Indian rest, after magnetic extraction. $M / M_{\mathrm{s}}$ relative magnetization (see discussion in text)

(661-680 $\mathrm{cm}^{-1}$; de Faria et al. 1997; Shebanova and Lazor $2003 \mathrm{~b}$ ), but a band above $670 \mathrm{~cm}^{-1}$ has been attributed by Hanesh (2009) to the ongoing transformation of magnetite reflecting possible maghemite. Furthermore, maghemite exhibits a band at $\sim 1,330-1,360 \mathrm{~cm}^{-1}$, which could contribute here to the apparent shift of the hematite $1,320 \mathrm{~cm}^{-1}$ band to a higher wave number (Hanesh, 2009). The band at about $634 \mathrm{~cm}^{-1}$, unusual in hematite, has been reported by Gehring et al. (2009) and interpreted as non-stoichiometric magnetite. The superposition of modes in the bright white parts of same reflectance and apparently homogeneous suggests that the size of some minerals is below the optical detection limit. It is thus concluded that the bands at about 634 and $675 \mathrm{~cm}^{-1}$ reflect the presence of maghemite or a non-stoichiometric transformation product of magnetite.

In the darker grayish patches, the spectra are slightly different (red spectrum in Fig. 9b). Besides well-defined peaks at $\sim 226,296,414,505$, and $1,328 \mathrm{~cm}^{-1}$ corresponding to hematite, shoulders on the flank of, or between defined bands are present, in comparison with the green spectrum from the bright patches (Fig. 9b). In the strong broad band at $669 \mathrm{~cm}^{-1}$, hidden peaks on its flanks are revealed by deconvolution at 565, 612, 730-740 $\mathrm{cm}^{-1}$. Similarly, a hidden peak can be found at $360 \mathrm{~cm}^{-1}$. These modes indicate thus the presence of relict magnetite $\left(565\right.$ and $669 \mathrm{~cm}^{-1}$ ) and of maghemite (360 and 730-740 $\mathrm{cm}^{-1}$, shown by red arrows in Fig. 9b) or another non-stoichiometric magnetite. The maghemite "diagnostic" bands (Hanesh 2009) are not well defined likely due to a small (less than micrometric) particle size. On this spectrum, the strong band at $\sim 665 \mathrm{~cm}^{-1}$ is attributed to both magnetite and maghemite.

\begin{tabular}{|lll|} 
Journal : Large 269 & Dispatch : 30-4-2014 & Pages : 17 \\
Article No : $\mathbf{6 7 9}$ & $\square$ LE & $\square$ TYPESET \\
MS Code : PCMI-D-13-00114 & $\square \quad$ CP & $\square$ DISK \\
\hline
\end{tabular}



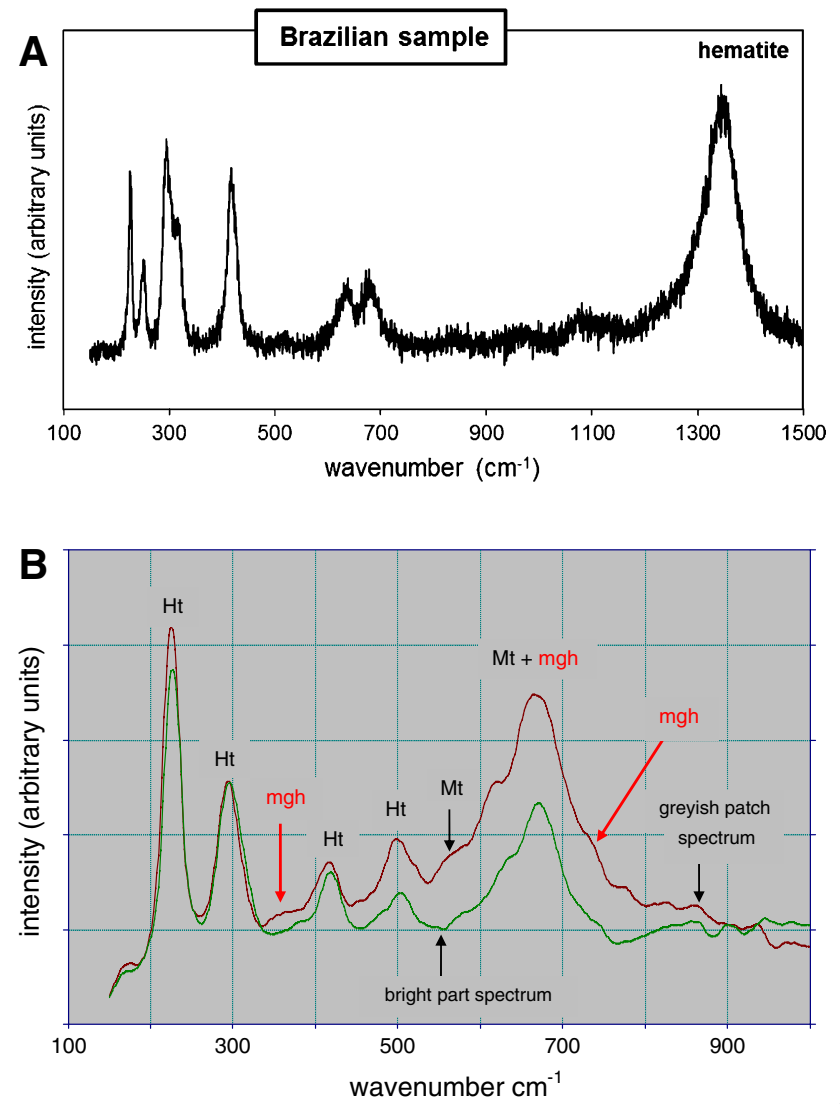

Fig. 9 Raman spectra from the Brazilian sample. a Hematite spectrum representative from the bright part. b In red, representative partial spectrum from darker grayish patches compared to hematite spectrum (in green). The shoulders (red arrows) are attributed after deconvolution to maghemite $(m g h)$ typical bands and magnetite (black arrow). The other well-defined bands are from hematite $(\mathrm{Ht})$, and the broad band at $\sim 665 \mathrm{~cm}^{-1}$ is attributed to both magnetite $(M t)$ and maghemite $(m g h)$

\section{Indian sample}

Raman spectra acquired in two different massive $\mathrm{Fe}$ oxide layers from the Indian sample share the following characteristics: spectra from the bright white spindleshape hematite trellis arranged parallel to [111] directions (Fig. 2c) show typical bands of hematite at 223226, 243-246, 291-298, 408-413, 495-503, 613-624, and $\sim 1,320 \mathrm{~cm}^{-1}$ (Fig. 10a). A band at $660-664 \mathrm{~cm}^{-1}$ may indicate the contribution from magnetite. Additional unresolved bands hidden in the fluorescence background between 800 and $1,200 \mathrm{~cm}^{-1}$ have also been reported by Hanesh (2009). The octahedral grains contain rare darker patches that have two different spectrum types: in type 1 , bands at $301,410,541$, and $666 \mathrm{~cm}^{-1}$ (Fig. 10b) are characteristic of magnetite, and in type 2, bands at 239243, 297-299, 383-385, 416-417, 479-480, 548-550, $\sim 681 \mathrm{~cm}^{-1}$ (Fig. 10c) reflect the presence of goethite (de

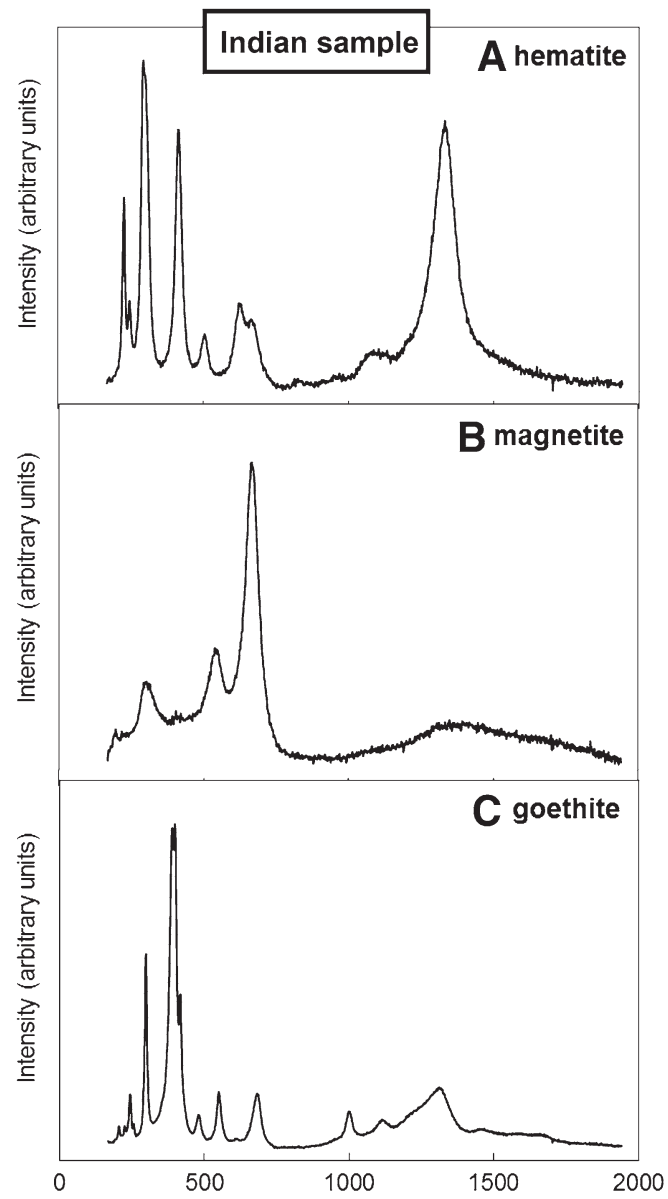

Fig. 10 Representative Raman spectra from the Indian sample. a Hematite from the bright hematite trellis, $\mathbf{b}$ magnetite; and $\mathbf{c}$ goethite from small rare darker patches (see discussion in text)

Faria et al. 1997; Hanesh 2009). The additional bands at $\sim 1,000, \sim 1,110$, and 1,300-1,314 $\mathrm{cm}^{-1}$ have also been reported for synthetic goethite (Hanesh 2009). Maghemite has not been observed.

\section{FIB-TEM}

\section{Brazilian sample}

In the Brazilian sample, two FIB-TEM foils were cut through magnetite (FIB foil 1; Fig. 11a, d) and through a hematite-magnetite part (FIB foil 2, Fig. 11e-i). FIB foil 1 represents a single magnetite crystal showing dislocations in some parts (arrow in Fig. 11a) and a patchy diffraction contrast (Fig. 11b, c). This mosaic texture of nanometersized Insel structures (black in Fig. 11b) likely indicates two phases slightly disorientated and/or with different stoichiometries. The presence of two different phases is confirmed by the splitting of the reflections in the SAED pattern (Fig. 11d). The major pattern shows lattice vector

\begin{tabular}{|l|lll|}
\hline Journal : Large 269 & Dispatch : 30-4-2014 & Pages : 17 \\
Article No : 679 & $\square$ LE & $\square$ TYPESET \\
MS Code : PCMI-D-13-00114 & $\square \quad$ CP & $\square \quad$ DISK \\
\hline
\end{tabular}


Fig. 11 FIB-TEM investigations on the Brazilian sample. FIB foil 1 in magnetite. a Overview of the magnetite crystal with an area rich in dislocations shown by the arrow (HAADF image). $\mathbf{b}$ and $\mathbf{c}$ Bright field $(B F)$ and complementary HREM images, respectively, showing a patchy diffraction pattern. d SAED pattern indexed as magnetite $(m g t)$. The splitting of the highest intense peaks reveals the presence of possible maghemite (mht). FIB foil 2 through hematite and magnetite. e HAADF image of the foil showing the NW-SE crystal boundary between hematite $(\mathrm{hm})$ and magnetite ( $\mathrm{mag}$ ). f BF image of lamellae within the hematite crystal. $\mathbf{g}$ and $\mathbf{h} \mathrm{BF}$ image showing the directions of two sets of twins and HREM image of a twin set in the hematite matrix, respectively.

i SAED pattern of hematite with split peaks reflecting a second diffraction pattern that could not be indexed
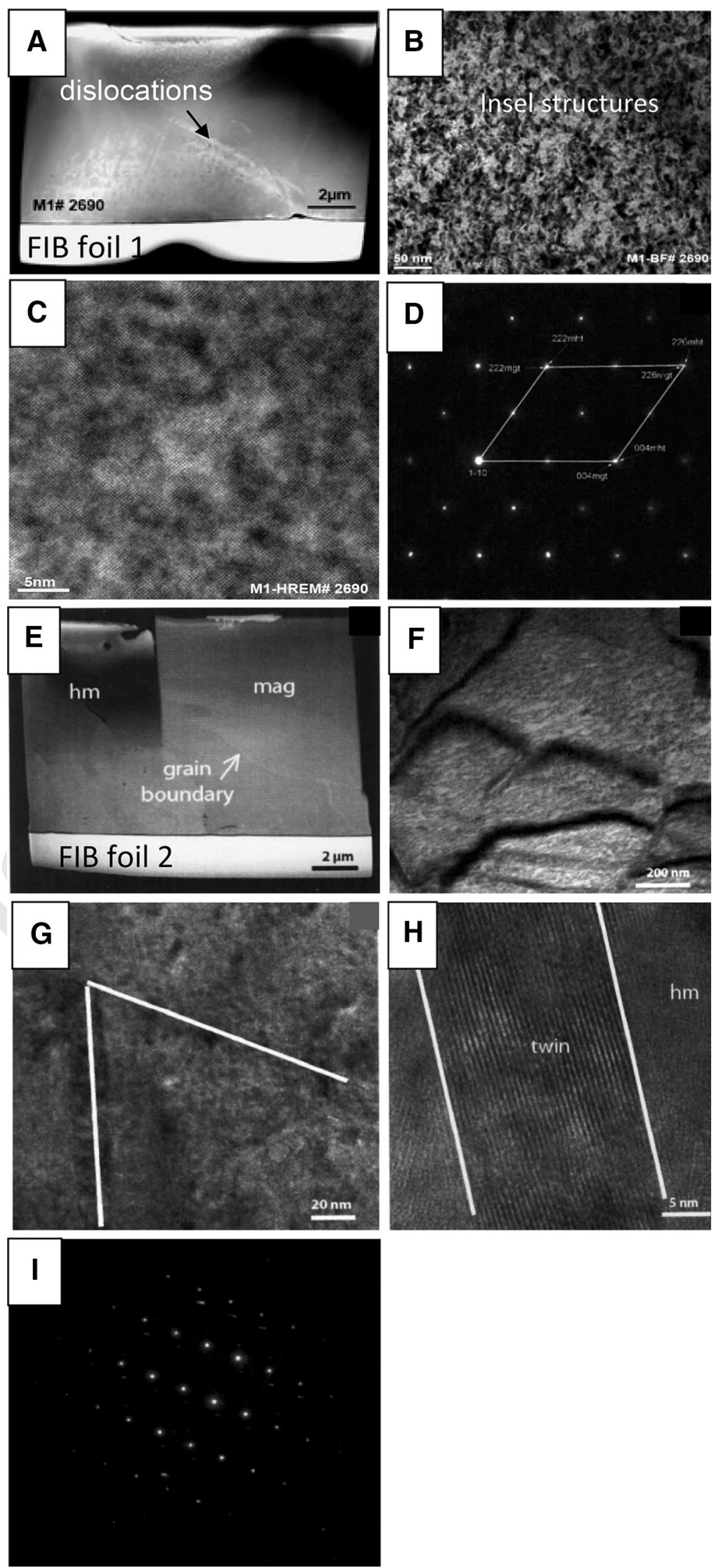

\begin{tabular}{|l|ll|} 
Journal : Large 269 & Dispatch : 30-4-2014 & Pages : 17 \\
Article No : 679 & $\square$ LE & $\square$ TYPESET \\
MS Code : PCMI-D-13-00114 & $\square \quad$ CP & $\square$ DISK \\
\hline
\end{tabular}


lengths of 0.4115 and $0.4756 \mathrm{~nm}$ with an angle of $54.7^{\circ}$ between planes (100) and (111) and lengths of 0.4756 and $0.4737 \mathrm{~nm}$ with an angle of $70.53^{\circ}$ between planes $(-111)$ and (111), lengths characteristic of magnetite. The second crystal indexed from the split peaks shows the same cubic system, but shorter lengths of the diffraction vector $(111=0.4461$ and $0.4756 \mathrm{~nm})$, indicating a shrinking of the crystal lattice and is probably maghemite within magnetite (Fig. 11d).

FIB foil 2 shows Z-contrasted parts of hematite and magnetite (Fig. 11e). The hematite crystals show scattering areas resulting in a patchy contrast as in the magnetite of FIB foil 1 and contain lamellae and twins (Fig. 11f, h). There are at least two sets of simple twins occurring along the (011) planes at angles of $64^{\circ}$ and with widths between 7 and $40 \mathrm{~nm}$ (Fig. 11g, h). The SAED pattern from the hematite part (Fig. 11i) reveals a second diffraction pattern behind the hematite pattern, as observed in FIB foil 1. For both sets of twins, the second diffraction pattern (not shown) can be indexed as magnetite or maghemite (or another non-stoichiometric magnetite). The SAED image acquired in the magnetite part only shows magnetite reflections.

\section{Indian sample}

The FIB foil cut in the Indian sample (Fig. 12a) shows numerous subhedral and interstitial crystals, magnetite and hematite (Fig. 12b), as indexed from the SAED patterns (Fig. 12c, d). As in the Brazilian sample, the magnetite SAED pattern shows split peaks (magnetite and maghemite; Fig. 12c). The d-spacings of the a-axes were 0.421 and $0.414 \mathrm{~nm}$ corresponding to magnetite and hematite, respectively. All the magnetite crystals have the same orientation, and their curved interface suggests evidence for grain boundary migration (Fig. 12b). Lamellae, similar to those observed in the Brazilian sample, are present in both magnetite and hematite, but they are much more defined in magnetite (Fig. 12e). The interstitial hematite crystals are characterized by dislocations and a high porosity with fluid inclusions along the dislocation lines (Fig. 12f, g).

\section{Discussion}

\section{Cross-cutting results from the different methods}

XRD detected hematite as the major compound in both samples. The presence of magnetite was identified by the shoulder of the peak at $\sim 2.52 \AA$ in the long-term run of the Brazilian sample and by the clear splitting of this peak in the magnetic fraction of the Indian sample, while peaks at 2.96 and $1.61 \AA$ in both samples could be attributed to both magnetite and maghemite. Although it is difficult to discriminate between magnetite and maghemite as both have a spinel structure, the presence of maghemite is attested in both samples by the peak at $2.78 \AA$. Goethite was identified in the Indian sample. The clear differences in the magnetic behavior of hematite and magnetite (easily magnetized and demagnetized) allow identifying a higher content of hematite compared to magnetite in the Brazilian sample than in the Indian sample, inferred from the relative magnetization and the shape of the hysteresis loops. Moreover, maghemite was detected in the Brazilian sample and suspected in the Indian sample. Common 300-K Mössbauer spectroscopy detected hematite in both samples, and magnetite and goethite in the Indian sample, but no maghemite. In-field Mössbauer spectroscopy would help detecting maghemite (Tuček and Zboril 2005). Raman spectroscopy identified hematite in the overall bright parts of the martite grains and magnetite in small darker patches from both samples. Moreover, maghemite or another non-stoichiometric magnetite was identified in the Brazilian sample. Goethite was found in the Indian sample. FIB-TEM analyses detected hematite, magnetite and maghemite in both samples and allowed to determine the phase relation and structures. In the Brazilian sample, maghemite occurs as nanometer-sized blocks arranged in a mosaic texture within magnetite or in twin sets in hematite. In the Indian sample, magnetite and maghemite occurred as subhedral crystals, while hematite forms the interstitial crystals hosting dislocations and fluid inclusions.

\section{Processes of magnetite to hematite transformation}

During the replacement of magnetite by hematite, $\mathrm{Fe}^{2+}$ ions diffuse through defects of the oxygen framework to surface sites where they are oxidized and either added to the surface or removed by solution (Davis et al. 1968; Lindsley 1976). This leads to vacancies in the spinel structure and the formation of cation-deficient magnetite or of maghemite, which converts to hematite. Alternatively, the transformation of magnetite to hematite may also result from non-redox reactions involving the leaching of $\mathrm{Fe}^{2+}$ ions by acidic solutions (Ohmoto 2003; Otake et al. 2007). In both cases, the transformation is accompanied by volume changes. While the redox-driven transformation implies a small volume increase, the non-redox transformation of magnetite to hematite results in a large volume decrease, which would be associated with a large volume of pore spaces created by the leaching of $\mathrm{Fe}^{2+}$ ions (Mücke and Cabral 2005).

\begin{tabular}{|llll|} 
Journal : Large 269 & Dispatch : 30-4-2014 & Pages : 17 \\
Article No : 679 & $\square \quad$ LE & $\square$ TYPESET \\
MS Code : PCMI-D-13-00114 & $\square \quad$ CP & $\square$ DISK \\
\hline
\end{tabular}



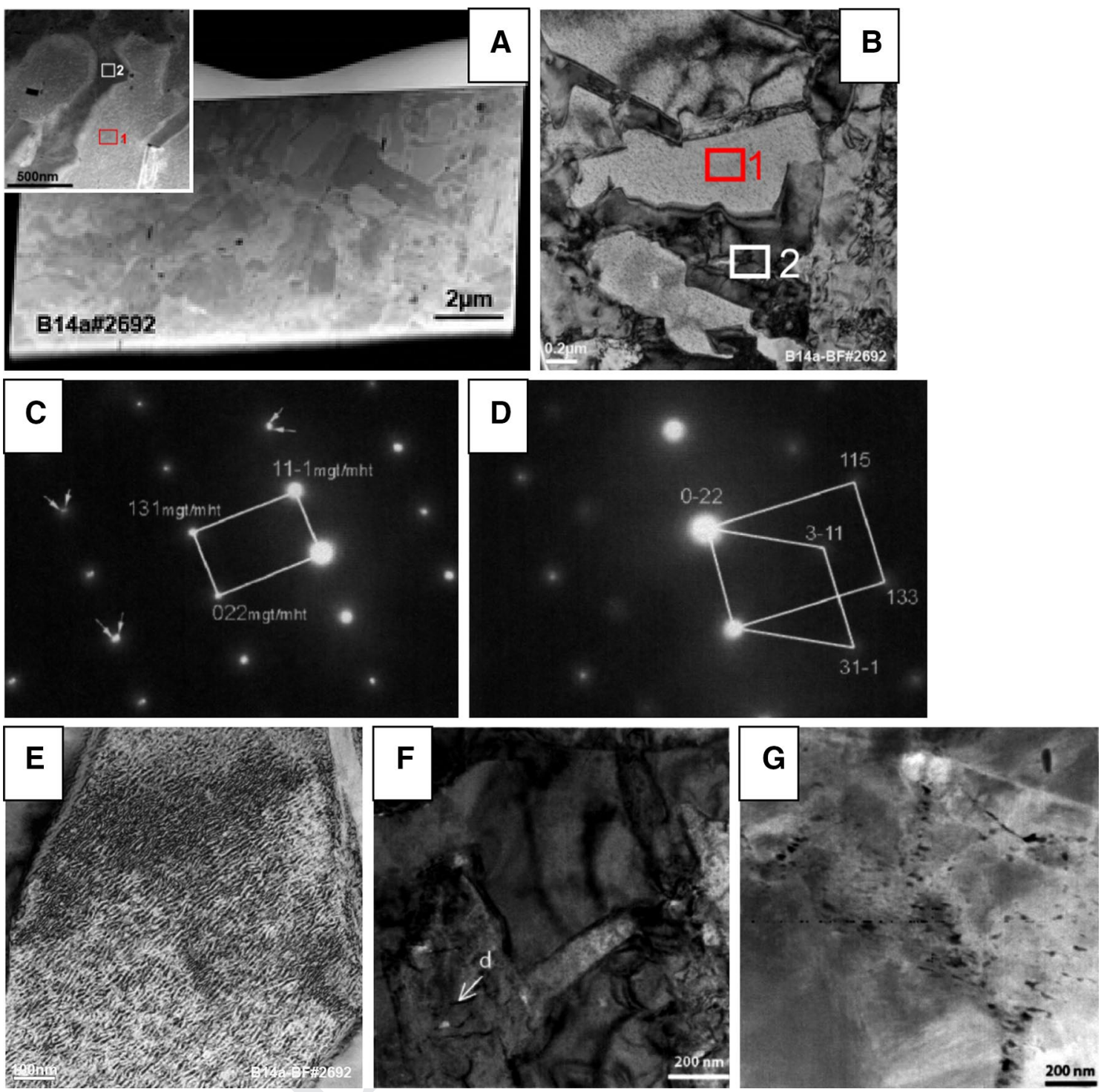

Fig. 12 FIB-TEM investigations on the Indian sample. a. Overview of the FIB foil (HAADF image) with a zoomed inset. It shows the interface between numerous subhedral bright (1) and interstitial darker (2) crystals. b BF image of the curved interface between magnetite (1) and hematite (2). C. SAED pattern of the subhedral mag- netite, which shows the splitting of the diffraction peaks, indexed as magnetite $(m g t)$ and maghemite $(m h t)$. d SAED pattern of the interstitial hematite. e BF image of the lamellae in magnetite. $\mathbf{f}$ High density of dislocations $d$ (BF image). $\mathbf{g}$ High porosity and fluid inclusions in the hematite interstitial crystals (HAADF image)
The Indian martite shows a trellis structure similar to the mesh-textured martite reported in different BIFs from Western Australia (e.g., Morris 1980, 1985; Angerer et al. 2012). The trellis structure may be weathering-related by oxidation of magnetite (Angerer et al. 2012), as well as hydration of maghemite (Morris 1980, 1985) or non-stoichiometric magnetite. The latter process leads to the formation of goethite, which is subsequently leached. However, trellis textures may be also caused through deuteric high-temperature oxidation followed by hydrothermal alteration (Alva-Valdivia and Urrutia-Fucugauchi 1998).
In the Indian martite, the lamellae observed in the magnetite grains may reflect magnetite-maghemite intergrowths (Fig. 12e). The presence of magnetite and maghemite in the subhedral crystals and interstitial crystals of hematite may suggest an exsolution process along parting planes leaving behind subhedral magnetite crystals with the same crystallographic orientation. The curved interfaces between magnetite-maghemite and hematite indicate typical grain boundary migrations and dynamic crystallization of hematite, being related to a deformation event. Furthermore, the observed porosity and the fluid inclusions in the

\begin{tabular}{|l|ll|} 
Journal : Large 269 & Dispatch : 30-4-2014 & Pages : 17 \\
Article No : 679 & $\square$ LE & $\square$ TYPESET \\
MS Code : PCMI-D-13-00114 & $\square \quad$ CP & $\square \quad$ DISK \\
\hline
\end{tabular}


hematite interstitial crystals point to the presence of a fluid along the hematite interface. This interpretation is consistent with the geological environment: the Indian martitehosting BIF was affected by greenschist facies metamorphism related to the emplacement of the post-kinematic Chitradurga granite $(2.60 \pm 0.02 \mathrm{Ga})$ and to gold mineralization during compressional tectonics at $2.52 \mathrm{Ga}$ (Taylor et al. 1984; Kolb et al. 2004; Jayananda et al. 2006; Sarma et al. 2011). These oxidizing hydrothermal fluids dissolved carbonate minerals and precipitated hematitemagnetite spherules in cavities (Orberger et al. 2012). The transformation from magnetite into hematite and the trellis formation are thus attributed to this hydrothermal event, as proposed by Beukes et al. (2008) for the origin of porous martite from the Archean BIFs at Noamundi, NE India. Later weathering is, however, indicated by the presence of goethite and the porous mesh texture resulting from its partial dissolution.

The Brazilian martite has no trellis, but shows irregular patches of magnetite within hematite, and neoformed euhedral tabular hematite crystals (Fig. 1b). Davis et al. (1968) attributed the epitaxial magnetite replacement by hematite to a relative volume decrease of 7.8 vol\% during the first step of the transformation of magnetite into maghemite. According to Barbosa and Lagoeiro (2010), the oriented growth of tabular hematite crystals is controlled by the octahedral planes of old magnetite grains, and, when dislocations are present, may be influenced by these crystal defects. For these authors, the direct transformation from magnetite into hematite occurs without the intermediate step of maghemite. However, the here studied martite clearly shows features indicating that the transformation comprises a maghemite step: (1) in hematite, the presence of lamellae and twins (Fig. 11h). The lamellae result from a structural change without chemical change, i.e., they still have the hematite chemistry, but a maghemite structure. The alignment along (111) of the structural defects created by the formation of maghemite is reflected by the observed lattice twins, the remnants of which are visible in the lamellae; (2) in magnetite, non-stoichiometric zones (Insel structures) and nano-scale dislocations, pointing to deformation (Fig. 11a, b). It is suggested that this deformation initiated the transformation from magnetite via maghemite into hematite along crystal planes. This scenario is in agreement with the geological history of the underlying phyllites and hydrothermal veins, which experienced later deformation (Cabral et al. 2011, 2012). The aboveoutlined arguments favor thus a fluid-deformation-induced magnetite-hematite transformation via a maghemite step prior to lateritization.

\section{Conclusion}

The analytical methods used during this study give complementary information, as different physical properties are analyzed at different scales. In both samples, hematite was detected as the major, and magnetite as the minor component, as these minerals have clear different magnetic behavior. Raman spectroscopy detects maghemite or a non-stoichiometric magnetite. XRD spectra show a small peak at $2.78 \AA$ indicative for maghemite. FIBTEM shows clear deformation structure (grains boundary migration, dislocations and twinning). Although deformation features differ in the two studied martites, in agreement with the geological environment, deformationinduced oxidizing fluids are proposed for the transformation of magnetite into hematite via a maghemite step for both samples. This study shows that martite found in supergene environment may result from earlier hypogene processes.

Acknowledgments This project was funded by the national PNP Planétologie, PRES UNIVERSUD Planétologie and the UMR IDES 8148 (CNRS-UPS) and COFECUB-CAPES (UPS, Orsay FranceUFMG, Belo Horizonte, Brazil). It was part of the ESF project "Early Habitats of Early life". The authors thank Rémy Pichon, Luce Delabesse, Valérie Godard and Olivier Dufour (UMR IDES), Gilles Montagnac (ENS-Lyon, Lyon) and Anja Schreiber (GFZ-Potsdam) for technical help. The authors thank M. Rieder for handling the manuscript, A. Cabral, H. Siemes and T. Angerer for comments and suggestions to fundamentally improve the manuscript.

\section{Appendix}

Raman spectra of goethite in the Indian sample. The spectra were acquired under the conditions reported in the text and at the same spot every $40 \mathrm{~s}$. Red lines correspond to the position of active modes for goethite (de Faria et al. 1997; Hanesh 2009). A band at $\sim 418 \mathrm{~cm}^{-1}$ (dashed red line) on the wing of the largest peak at $385 \mathrm{~cm}^{-1}$ has also been reported by Hanesh (2009). According to these authors, the broad bands above $1,000 \mathrm{~cm}^{-1}$ are not "diagnostic" for goethite and may record some contaminant species. Apart from a decrease in the background fluorescence between 1,000 and $1,400 \mathrm{~cm}^{-1}$ with increasing laser exposition time, there is no significant variation in the observed spectral modes, either in position or in intensity, for a total time of irradiation up to $8 \mathrm{~min}$. Moreover, there is no appearance of new bands, which would indicate a possible transformation of goethite under the laser beam (in maghemite or hematite; Hanesh 2009).

\begin{tabular}{|l|ll|} 
Journal : Large 269 & Dispatch : 30-4-2014 & Pages : 17 \\
Article No : 679 & $\square \quad$ LE & $\square$ TYPESET \\
MS Code : PCMI-D-13-00114 & $\square \quad C P$ & $\square$ DISK \\
\hline
\end{tabular}




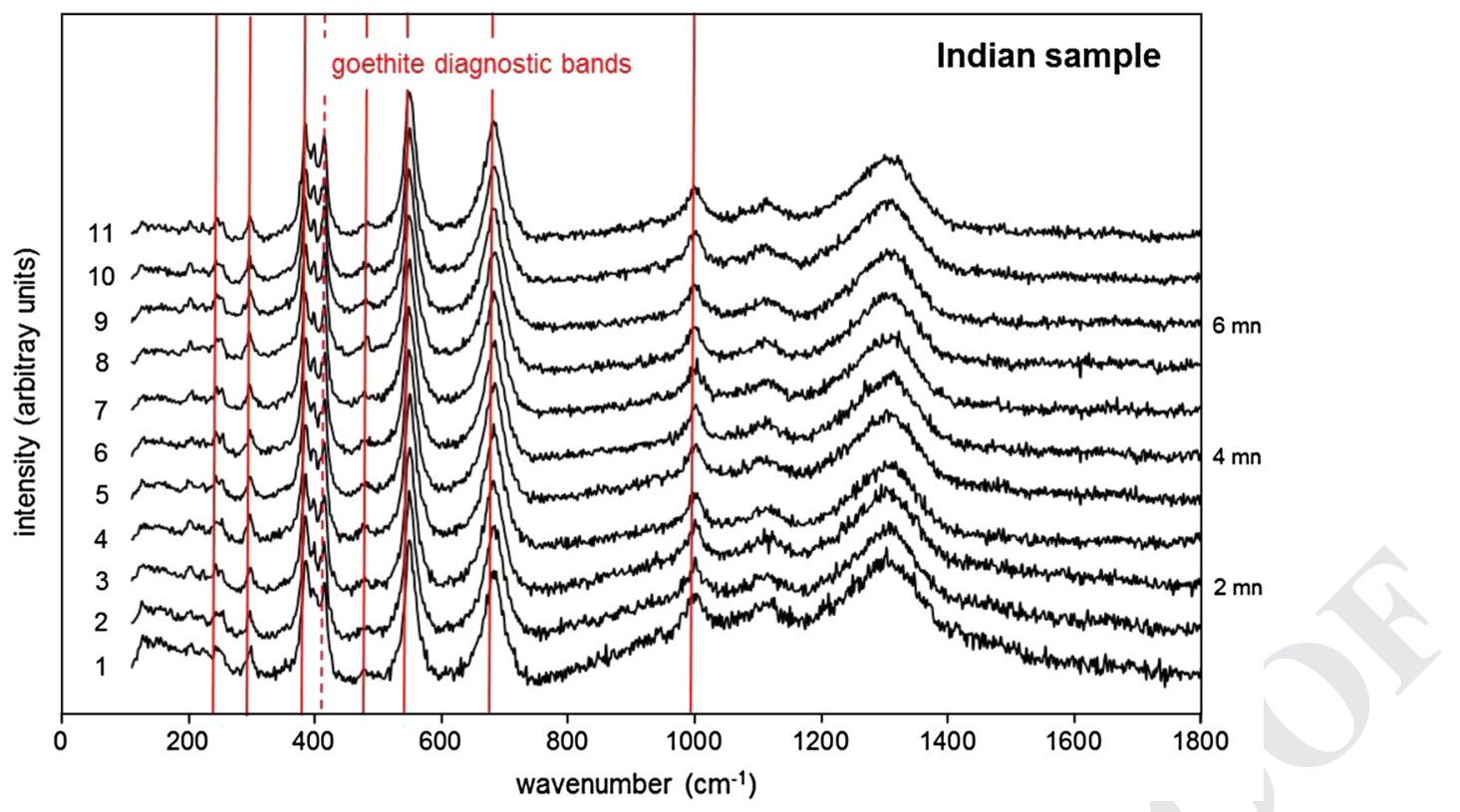

\section{References}

Alva-Valdivia LM, Urrutia-Fucugauchi J (1998) Rock magnetic properties and ore microscopy of the iron ore deposit of Las Truchas, Michoacan, Mexico. J Appl Geophys 38:277-299

Angerer T, Hagemann SG, Danyushevsky V (2012) Geochemical evolution of the Banded iron formation-hosted high-grade iron ore system in the Koolyanobbing Greenstone Belt, Western Australia. Econ Geol 107:599-644

Bachmann HG (1954) Uber Martiterze von Talberg (Viirmland) Schweden. Neues Jahrb Mineral 6:131-136

Banerji PK (1984) On some geochemical features of the vanadiferous magnetite deposits of Kumhardubi and Betjharan, Mayurbhanj district, Orissa, India. Chem Geol 43:257-269

Barbosa PF, Lagoeiro L (2010) Crystallographic texture of the magnetite-hematite transformation: evidence for topotactic relationships in natural samples from Quadrilátero Ferrífero, Brazil. Am Mineral 95:118-125

Beukes NJ, Mukhopadhyay J, Gutzmer J (2008) Genesis of highgrade iron ores of the Archean iron ore group around Noamundi, India. Econ Geol 103:365-386

Brown DA, Sherrif B, Sawick JA (1997) Microbial transformation of magnetite to hematite. Geochim Cosmochim Acta 61:3341-3348

Cabral AR, Lehman B, Tupinamba M, Wiedenbeck M, Brauns M (2011) Geology, mineral chemistry and tourmaline B isotopes of the Córrego Bom Sucesso area, southern. Serra do Espinhaço, Minas Gerais, Brazil: implications for $\mathrm{Au}-\mathrm{Pd}-\mathrm{Pt}$ exploration in quartzitic terrain. J Geochem Explor 110:260-277

Cabral AR, Wiedenbeck M, Koglin N, Lehmann B, de Abreu FR (2012) Boron-isotopic constraints on the petrogenesis of hematitic phyllite in the southern Serra do Espinhaço, Minas Gerais, Brazil. Lithos 140-141:224-233

Colombo U, Cazzarini F, Lanzavecchia G, Sironi E (1965) Magnetite oxidation: a proposed mechanism. Science 147:1033

Davis BL, Rapp G, Walawender MJ (1968) Fabric and structural characteristics of the martitisation process. Am J Sci 266:482-496

Day R, Fuller MD, Schmidt VA (1977) Magnetic hysteresis properties of synthetic titanomagnetites. Phys Earth Planet Inter 13:260-266

De Boer CB, Dekkers MJ (2001) Unusual thermomagnetic behaviour of haematites: neoformation of a highly magnetic spinel phase on heating in air. Geophys J Int 144:481-494 de Faria DLA, Venancio-Silva S, de Oliveira MT (1997) Raman microspectroscopy of some iron oxides and oxyhydroxides. J Raman Spectrosc 28:873-878

El Mendili Y, Bardeau JF, Randrianantoandro N, Gourbil A, Greneche JM, Mercier AM, Grasset F (2010) New evidence of in situ laser irradiation effects on $\gamma-\mathrm{Fe}_{2} \mathrm{O}_{3}$ nanoparticles: a Raman spectroscopic study. J Raman Spectrosc 42:239-242

Gehring AU, Fischer H, Louvel M, Kunze K, Weidler PG (2009) High temperature stability of natural maghemite: a magnetite and spectroscopic study. Geophys J Int 179:1361-1371

Gruner JW (1922) Organic matter and the origin of the Biwabik ironbearing formation of the Mesabi range. Econ Geol 17:407-460

Gruner JW (1926) Magnetite-martite-hematite. Econ Geol 21: 375-393

Gruner JW (1929) Structural reasons for oriented intergrowths in some minerals. J Mineral Soc Am 14:227-231

Hanesh M (2009) Raman spectroscopy of iron oxides and (oxy) hydroxides at low laser power and possible implications in environmental magnetic studies. Geophys J Int 177:941-948

Jayananda M, Chardon D, Peucat J-J, Capdevila R (2006) 2.61 Ga potassic granites and crustal reworking in the western Dharwar craton, Southern India: tectonic, geochronological and geochemical constraints. Precambrian Res 150:1-26

Joint Committee on Powder Diffraction Standard (1974) Selected powder diffraction data for minerals. Joint Committee on Powder Diffraction Standards, Pennsylvania

Kolb JH, Rogers A, Sinderen S, Vennemann T, Böttcher ME, Meyer FM (2004) The role of a transcrustal shear zone in orogenic gold mineralization at the Ajjanahalli mine, Dharwar craton, South India. Econ Geol 99:743-759

Kullerud G, Donnay G, Donnay JDH (1969) Omission solid solution in magnetite: kenotetrahedral magnetite. Z Kristallogr Bd 128:1-17

Kumar B, Das Sharma S (1998) Carbon isotope systematics of graphites from Dharwar craton, Southern India: implications to their source and post-depositional alterations. Curr Sci 75:396-397

Lagoeiro LE (1998) Transformation of magnetite to hematite and its influence on the dissolution of iron-oxide minerals. J Metamorph Geol 16:415-423

Lepp H (1957) Stages in the oxidation of magnetite. Am Mineral 42:679-681

\begin{tabular}{|l|ll|}
\hline Journal : Large 269 & Dispatch : 30-4-2014 & Pages : 17 \\
Article No : 679 & $\square$ LE & $\square$ TYPESET \\
MS Code : PCMI-D-13-00114 & $\square \quad$ CP & $\square$ DISK \\
\hline
\end{tabular}


Lindsley DH (1976) Experimental studies of oxide minerals. In: Rumble D III (ed) Reviews of mineralogy, oxide minerals, vol 32, 2nd edn. BookCrafters, Chelsea, pp L61-L88

Morris RC (1980) A textural and mineralogical study of the relationship of iron ore to banded iron ore formation in the Hamersley iron province of Western Australia. Econ Geol 75:184-209

Morris RC (1985) Genesis of iron ore in banded iron formation by supergene and supergene-metamorphic processes-a conceptual model. In: Wolf KH (ed) Handbook of strata-bound and stratiform ore deposits, vol 13. Elsevier, Amsterdam, pp 73-235

Mücke A, Cabral AR (2005) Redox and non-redox reactions of magnetite and hematite. Chem Erde 65:271-278

Ohmoto H (2003) Non-redox transformations of magnetite-hematite in hydrothermal systems. Econ Geol 98:157-161

Orberger B, Wagner C, Wirth R, Quirico E, Gallien JP, Derré C, Montagnac G, Noret A, Jayananda M, Massault M, Rouchon V (2012) Origin of iron-oxide spherules in the banded iron formation of the Bababudan Group, Dharwar Craton, Southern India. J Asian Earth Sci 52:31-42

Otake T, Wesolowski DJ, Anovtz LM, Allard LF, Ohmoto H (2007) Experimental evidence for non-redox transformations between magnetite and hematite under $\mathrm{H}_{2}$-rich hydrothermal conditions. Earth Planet Sci Lett 257:60-70

Roberts AP, Cui Y, Verosub KL (1995) Wasp-waisted hysteresis loops: mineral magnetic characteristics and discrimination of components in mixed magnetic systems. J Geophys Res 100(B9):17909-17924

Sarma SD, Fletcher IR, Rasmussen B, McNaughton NJ, Mohan MR, Groves DI (2011) Archean gold mineralization synchronous with late cratonization of the Western Dharwar Craton, India: $2.52 \mathrm{Ga}$ $\mathrm{U}-\mathrm{Pb}$ ages of hydrothermal monazite and xenotime in gold deposits. Miner Depos 46:273-288

Shebanova ON, Lazor P (2003a) Raman study of magnetite $\left(\mathrm{Fe}_{3} \mathrm{O}_{4}\right)$ : laser-induced thermal effects and oxidation. J Raman Spectrosc 34:845-852

Shebanova ON, Lazor P (2003b) Raman spectroscopic study of magnetite $\left(\mathrm{FeFe}_{2} \mathrm{O}_{4}\right)$ : a new assignment for vibrational spectrum. J Solid State Chem 174:424-430
Srinivasan R, Ojakangas RW (1986) Sedimentology of quartz-pebble conglomerates and quartzites of the Archaean Bababudan Group, Dharwar Craton, South India: evidence for early crustal stability. J Geol Soc India 94:199-214

Swanson-Hysell NL, Feinberg JM, Berquô TS, Maloof AC (2011) Self-reversed magnetization held by martite in basalt flows from the 1.1 billion-year-old Keweenawan-rift, Canada. Earth Planet Sci Lett 325:171-184

Tarling DH (1983) Paleomagnetism, principles and applications in geology, geophysics and archaeology. Chapman and Hall, New York

Tauxe L, Mullender TAT, Pick T (1996) Potbellies, wasp-waisted, and superparamagnetism in magnetic hysteresis. J Geophys Res 101(B1):571-583

Taylor PN, Chadwick B, Moorbath S, Ramakrishanan M, Viswanatha MN (1984) Petrography, chemistry and isotopic ages of peninsular gneisses, Dharwar, acid volcanics and Chitradurga granite with special reference to Archaean evolution of Karnataka craton, Southern India. Precambrian Res 23(3-4):349-375

Thompson R, Oldfield M (1986) Environmental magnetism. Allen and Unvin, London

Tuček J, Zboril R (2005) Zero-field and in-field Mössbauer spectroscopy as a tool for structural and magnetic characterization of maghemite $\left(\gamma-\mathrm{Fe}_{2} \mathrm{O}_{3}\right)$ nanoparticles. Czechoslov J Phys 55:893-911

Wasilewski P (1973) Magnetic hysteresis in natural materials. Earth Planet Sci Lett 20:67-72

Weber H-P, Hafner SS (1971) Vacancy distribution in nonstoichiometric magnetites. Z Kristallogr New Cryst Struct 133:327-340

Wirth R (2004) Focused Ion Beam (FIB): a novel technology for advanced application of micro-and nanoanalysis in geosciences and applied mineralogy. Eur J Mineral 16:863-876

Wirth R (2009) Focused ion beam (FIB) combined with SEM and TEM: advanced analytical tools for studies of chemical composition, microstructure and crystal structure in geomaterials on a nanometer scale. Chem Geol 261:217-229 